This item was submitted to Loughborough's Research Repository by the author.

Items in Figshare are protected by copyright, with all rights reserved, unless otherwise indicated.

\title{
Understanding satisfying service encounters in retail banking - a dyadic perspective
}

\section{PLEASE CITE THE PUBLISHED VERSION}

http://dx.doi.org/10.1504/IJSEM.2013.054950

PUBLISHER

(C) Inderscience

VERSION

AM (Accepted Manuscript)

LICENCE

CC BY-NC-ND 4.0

\section{REPOSITORY RECORD}

Kania, Nathalie, and Thorsten Gruber. 2019. "Understanding Satisfying Service Encounters in Retail Banking - a Dyadic Perspective". figshare. https://hdl.handle.net/2134/13894. 
This item was submitted to Loughborough's Institutional Repository (https://dspace.lboro.ac.uk/) by the author and is made available under the following Creative Commons Licence conditions.

\section{creative
commons}

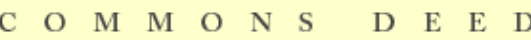

Attribution-NonCommercial-NoDerivs 2.5

You are free:

- to copy, distribute, display, and perform the work

Under the following conditions:

Attribution. You must attribute the work in the manner specified b the author or licensor.

Noncommercial. You may not use this work for commercial purposes.

No Derivative Works. You may not alter, transform, or build upon this work.

- For any reuse or distribution, you must make clear to others the license terms of this work.

- Any of these conditions can be waived if you get permission from the copyright holder.

Your fair use and other rights are in no way affected by the above.

This is a human-readable summary of the Leqal Code (the full license).

\section{Disclaimer 만}

For the full text of this licence, please go to: http://creativecommons.org/licenses/by-nc-nd/2.5/ 


\title{
Understanding satisfying service encounters in retail banking - a dyadic perspective
}

\author{
Nathalie Kania \\ IronFX Financial Services Ltd, \\ 2 Lapetou Street, Agios Athanasios, 4101 Limassol, Cyprus \\ Email: nathaliekania@gmail.com
}

\author{
Thorsten Gruber* \\ The University of Manchester, \\ Manchester Business School \\ Booth Street West \\ Manchester M15 6PB, UK \\ Tel.: +44-(0)161-275 6479 \\ Email: thorsten.gruber@mbs.ac.uk \\ *Corresponding author
}

\begin{abstract}
The aim of this study is to expand understanding of satisfying service encounters. In particular, this research study will investigate both parties of the service encounter (customers and frontline employees). A dyadic approach will help to identify whether customer expectations differ from what contact employees believe customers desire from the service encounter. Insights will then lead to a greater understanding of the service encounter as revealed discrepancies in perceptions will not only increase employees' and management awareness, but also provide implications for training and recruitment of employees. An exploratory research study using the well-established laddering interviewing technique was regarded as appropriate as it allows researchers to gain a deeper insight into the research subject. In total, in-depth laddering interviews with 40 respondents (20 customers and 20 frontline employees) were conducted.The findings of this study suggest that customers and employees identified several similar concepts as being important for a successful service encounter such as friendliness, competence, responsiveness, honesty, and communication skills.
\end{abstract}

Keywords: service encounter, service quality, retail banking, dyadic approach, customer satisfaction, customer expectations, frontline employee behaviour, service dominant logic, means-end approach, laddering

Biographical notes: Ms Nathalie Kania is a Marketing Communication Officer at IronFX Financial Services Ltd. She holds a MSc Marketing from the University 
of Manchester, Manchester Business School and a BA (Hons) in Business Administration from Manchester Metropolitan University.

Dr. Thorsten Gruber is a Senior Lecturer (Associate Professor) in Marketing and Service Management at Manchester Business School, University of Manchester, UK. Prior to that, he was engaged in postdoctoral research at the Birmingham Business School, University of Birmingham and a part-time visiting lecturer at the University of Education, Ludwigsburg. He received his Ph.D. and M.B.A. from the University of Birmingham. His research interests include consumer complaining behavior, services marketing, and the development of qualitative online research methods. His work has been published in journals such as Journal of the Academy of Marketing Science, Journal of Product Innovation Management, Journal of Business Research, Industrial Marketing Management, Journal of Services Marketing, Journal of Service Management, and Journal of Marketing Management. 


\section{Introduction}

In order to differentiate themselves in the competitive marketplace, service providers are driving for service excellence by continuously improving service quality (Berry and Parasumaran, 1991). Growth and value creation have thus become the dominant theme and human interactions between companies and customers are becoming the focus of value creation (Ostrom et al., 2010; Payne et al., 2008; Prahalad and Ramaswamy, 2004).

Furthermore, it has been recognised that value can only be co-created with the customer. The proposition that the customer becomes a co-creator of value is at the core of the concept of servicedominant logic (S-D logic), which has generated new insights into our understanding of marketing and management (Vargo and Lusch, 2004). It therefore becomes critical to focus on the development of customer-service provider relationships through interaction and dialogue. These relationships usually develop at the service encounter between customers and frontline employees (Payne et al., 2008). Interactions between customers and employees are thus central for value creation.

Due to the fact that employees' attitudes and their behaviour at the service encounter can positively or negatively influence customers' perceptions of service quality, it is important that companies focus their resources on ensuring that such service encounters are delivered in a reliable and consistent manner (Zomerdijk and Voss, 2010). Through continuous investment in the workforce and effective human resources practices companies will ultimately foster their organisational competences and be able to compete successfully in a global marketplace characterised by intensive competition (Bitner and Brown, 2008).

The aim of this research is to compare customers' with employees' perceptions of a satisfying service encounter in a banking context. Moreover, the study will focus on face-to-face service 
encounters as these occur most frequently in the banking context due to the interactive nature of the service. A dyadic approach was considered to be useful for understanding service encounters as it reflects the dynamics of service quality of a personal service encounter (Svensson, 2006).

\section{Principles of service-dominant logic (S-D logic)}

The emerging marketing and management framework of service-dominant logic (S-D logic) holds that all companies and customers exchange service for service as the fundamental basis of exchange (Vargo and Lusch, 2004; 2006; 2008abc; 2011). According to this view, service is defined as the application of knowledge and skills to co-create value. S-D logic also distinguishes between operand and operant resources. Operand resources are defined as resources on which an operation or act is performed to produce an effect, whereas operant resources are resources that produce effects on other operant or operand resources. Operant resources can be core competences, knowledge and skills and they are conceptualised as primary resources as they are producers of effects (Lusch and Vargo, 2006). Value creation is regarded as a collaborative process of co-creation between different parties. This brings along the need of sharing information and engaging in joint problem solving, which relies on mutual trust between different parties in the co-creation process (Vargo, 2008).

“Competing through service” (Lusch et al., 2007, p. 8) therefore implies a company’s strategic vision characterised by on-going relationships and collaboration with customers, employees and network partners in order to overcome internal and external resistances. The companies hereby need to draw upon internal and external resources, leading ultimately to value creation for all stakeholders. It is therefore important to achieve a meaningful dialogue and an understanding of each member's role in the network in the value creation process (Vargo and Lusch, 2008b). Customers, partners and the external environment have thus to be viewed as operant resources (Lusch et al., 2007). 
The most important tenet of the concept of S-D logic for this study is the suggestion that "value can only be determined by the user in the 'consumption process' and the idea of co-creation of value is closely tied to "value-in-use"” (Lusch et al., 2007, p.11). Value can only be created in interaction with the customer and the company cannot deliver value, but only offer value propositions to the customer (Vargo, 2008; 2009). The concept of value-in-use is understood as being the experience of a customercentred process whereby customers use their own private and public resources in co-creation with the service provider's private and public resources to create value. Therefore, both parties, the company and customer, are resource integrators and beneficiaries of the exchange (Vargo et al., 2008). Furthermore, the company follows a 'market with' philosophy instead of a 'market to' philosophy with the implication that customers need to be involved in the production and delivery process as customers have the desire to be part of the service operations (Lusch et al., 2007). Value is therefore seen as an experiential, contextual and meaning-laden construct (Vargo et al., 2008).

The aim of an organisation is to offer service quality, to invest in operant resources (employees) and to create long-term relationships. Various researchers argue that especially the financial service sector has a strong focus on building lasting relationships with customers (Barnes, 1997; Greene et al., 1994; Kelemen and Papasolomou, 2007; Tansuhaj et al., 1987). It was therefore decided to focus on this important service industry.

\section{The crucial role of service encounters}

Vargo and Lusch (2007) suggest that concepts such as the service encounter are at the heart of S-D logic. Similarly, according to service experts a continued exploration of the service encounter is important for the future of services marketing (Grove et al., 2003). More recently, Kunz and Hogreve (2011, p. 244) suggested that "a stronger focus on employee-customer interactions during service encounters" would be necessary for the future of service research. 
Solomon et al. (1985) define service encounters as person-to-person interactions between customers and service providers. Interactions with the service provider, hence the employees, play a vital role in the customer's perception related to quality and ultimately determine satisfaction (Bitner et al., 1990). In retail banking, customer satisfaction is based on the evaluation of multiple interactions between the employee and the customer (Jamal and Naser, 2002). Therefore, it is important that employees know their roles as their behaviour in the current service encounter determines success in future service encounters (Broderick, 1999).

The service encounter has a crucial role in service differentiation and quality control (Solomon et al., 1985). According to Czepiel et al. (1985) the outcome of the dyadic interaction is the service experience created by both parties and the challenge for organisations is to control these service experiences. As value can only be created in interactions with the customer (Vargo and Lusch, 2004), it is therefore important to examine the perspectives of both participants in the service encounter.

\section{The important role of service quality for customers}

Over the last two decades, research on service quality has grown extensively and substantively (Grönroos, 2007). Moreover, Kunz and Hogreve (2011), who recently analysed the structure and evolution of the service research field, revealed that service quality articles make the most important contributions to the discipline.

The importance of service quality research is also reflected in developments in the business sector. Consumers nowadays are more educated and aware of alternative services, urging organisations to differentiate their offerings in order to maintain a competitive advantage (Lewis and Gabrielson, 1998). It is thus critical to improve customers' perceptions regarding service quality, as they influence customer satisfaction and brand perception. This will on the other hand increase long-term loyalty, lead to positive word-of-mouth and higher profitability for the company (Fisk et al., 1993; Tam and Wong, 2001). 
As a consequence, service companies strive for 'zero defections' with the aim to retain customers the company can profitable serve, and through learning from defecting customers, companies intent to continuously improve service quality (Reichheld and Sasser, 1990).

According to Bowen and Hedges (1993), achieving superior levels of service quality is a critical imperative for retail banks, leading to increased market share and shareholder value. Banks need to focus hereby on reducing customer defection rates, as this will ultimately lead to an increase in value for the company and customer (Beaujean et al., 2007). Increased loyalty can lead to reduced servicing costs, improved comprehension of customer needs, more effective targeting and increased opportunities of cross-selling of financial products and services (Levesque and McDougall, 1996). Therefore, banks need to focus on a differentiation strategy by providing their customers with a high quality banking service, leading to enhanced customer satisfaction (Bedi, 2010).

Service quality is argued to be based on the disconfirmation paradigm, suggesting that quality results from a comparison of customer perceived with expected performance (Grönroos, 2007; Parasuraman et al., 1985, 1988). It is therefore important for the company to have adequate knowledge about customer needs in order to improve service quality (Grönroos, 2007). According to Beaujean et al. (2007) gaining customer insights through market research has to be seen as a continuous journey for the banking industry. Cooperation throughout all the departments of the bank will then result in innovative strategies for the customer.

Customer expectations exist at two different levels, a desired and adequate level. The desired service reflects the service the customer hopes to receive, whereas the adequate level of service refers to the level of service the customer will accept. A zone of tolerance is the extent to which the customer is willing to accept a deviation in performance as a performance below the tolerance level will decrease 
customer satisfaction and loyalty, whereas a performance above it will delight the customer (Parasumaran et al., 1991). The aim for the organisation is thus to meet or exceed customer expectations.

Nadiri et al. (2009) found that customers use these two types of expectations in evaluating the service experience in banks. Similarly, Beaujean et al. (2007) argue that banks attempt to exceed customer expectations increasingly. Holmlund and Kock (1996) posit that service quality has to at least meet customer expectations; otherwise the customer will be inclined to switch to another bank. If a bank promises more than that it can actually deliver, it can lead to bad word-of-mouth, result in complaints and hence, damage the company's reputation (Papasolomou and Vrontis, 2006).

From an S-D logic perspective it is crucial for companies to understand what customers expect as companies can then make value propositions that hopefully will be perceived to be of value by their customers. Moreover, Bitner and Brown (2008) argue that in practice many service businesses still focus on productivity improvements and operational efficiency, rather than on co-creating value with their customers. More recently, Ostrom et al. (2010) pointed out the need for studies on the co-creation of value as insights are needed into creating value for the customer and capturing value for the company.

\section{The important role of frontline employees}

Frontline employees play a crucial role in satisfying service encounters as their behaviours and attitudes primarily determine the customers' perceptions of service quality (Hartline and Ferrell, 1996). Similarly, Bitner et al. (1994, p. 95) suggest that for services, "customer satisfaction is often influenced by the quality of the interpersonal interaction between the customer and the contact employee". Frontline employees shape the 'moments of truth' not only by the tasks they perform, but also by the way they look, talk and interact with customers (Bitner et al., 1994). Further, Pieters et al. (1998) suggest that the behaviours of service employees have a strong impact on customers' ability to attain their goals. 
As frontline employees' behaviours and performances determine service quality, companies must carefully manage them. For example, it becomes imperative for employees to be taught their role in the service delivery process and to know the company's offerings. According to Bitner et al. (1990), customers evaluate the service encounter based on the employee's ability to deliver the service right the first time, their attitudes and actions and how well they deal with special requests, and to recover in cases of a service failure. Therefore, in order to deliver the service promises to customers, employees must have the abilities, skills, tools and motivation to deliver the service (Bitner, 1995). It is thus critical to recruit and select the right staff and to have training programmes in order to make the service encounter as effective as possible (Lewis and Entwistle, 1990).

Furthermore, employees are not only expected to fulfil physical labour, but also emotional labour which is defined as the employee's ability to work on emotion in order to present a socially desirable performance (Hochschild, 1983). Emotional labour is the act of attempting to change an emotion or feeling so that it is appropriate for any given situation such as smiling during the service encounter and showing genuine concern for customer needs (Blake and Humphrey, 1993). Employees thus need to be able to be empathetic, responsive and show that they care about customers (Barger and Grandey, 2006).

By engaging with customers, employees can create rapport which is defined as "a customer's perception of having an enjoyable interaction with a service provider employee, characterised by a personal connection between the two interactants“ (Gremler and Gwinner, 2000, p.92). The authors further argue that rapport includes feelings of care and friendliness and personal connections which can be created through psychological similarity or a genuine interest in the other party. Rapport is considered to be important for the development of relationships, and the creation of a successful relationship can positively influence customer satisfaction, loyalty and word-of mouth recommendation (Price and Arnould, 1999; Pullman and Gross, 2004). 


\section{Research objectives}

Following an extensive review of the literature it can be concluded that the role of frontline employees is central in order to improve the customer's perceived service quality during the service encounter.

However, service quality has predominately been conceptualised from the service receiver's perspective. Therefore, existing service quality models seem to neglect the service provider's perspective and especially the role of employees in the creation of quality. Surprisingly, only a few attempts have been made to investigate both perspectives in the service encounter (e.g. Chandon et al., 1997; Svensson, 2001).

In addition, the literature discussed demonstrates the importance of personal interactions between customers and employees during the service encounter. A dyadic approach therefore not only fits the nature of the service encounter but could also reveal important gaps between the different parties. Previous studies indicate large gaps between customers' and employees' perceptions of good service quality and what constitutes a satisfying service experience (Bitner et al., 1994; Matilla and Enz, 2002; Swartz and Brown, 1989). Similarly, according to a Bain \& Company survey with 362 leading firms from multiple geographical locations, $80 \%$ believed they delivered a 'superior experience' to their customers. In contrast, customers rated only $8 \%$ of companies as truly delivering a superior experience (Allen et al., 2005).

It was therefore decided to conduct an exploratory study in a well-established service industry (retail banking) to investigate this interesting phenomenon further. The aim is to expand understanding of satisfying service encounters. In particular, this research study will investigate both parties of the service encounter by using the well-established laddering technique (Reynolds and Gutman, 1988). A dyadic approach will help to identify whether customer expectations differ from what contact employees believe customers desire from the service encounter (Gruber et al., 2009a; Svensson, 2006). Insights will 
then lead to a greater understanding of the service encounter as revealed discrepancies in perceptions will not only increase employees' and management awareness, but also provide implications for training and recruitment of employees (Bitner et al., 1994).

\section{Methodology - Using laddering to investigate satisfying service encounters}

The well-established laddering in-depth interviewing technique was used to gain a deeper understanding of both customer and employee perceptions. Laddering is a valuable method especially for the exploratory stages of research projects (van Rekom and Wierenga, 2007). The technique has been used widely, originally for brand or product positioning issues (Gutman, 1982; Olson and Reynolds, 1983), and recently in research areas such as sales management (Deeter-Schmelz et al., 2008), services marketing (Gruber et al., 2006; 2009ab), higher education services (Voss et al., 2007), business-tobusiness marketing (Henneberg et al., 2009), health services (Gruber and Frugone, 2011), and ethical clothing consumption (Jaegel et al., 2012).

Laddering is generally employed to reveal the relationships which exist between the attributes of products, services or individuals ("means"), what consequences these attributes represent for the respondent, and the personal values or beliefs, which are strengthened or satisfied by the consequences (“end") (Reynolds and Gutman, 1988). Attributes are the tangible and intangible characteristics of a product or service. Consequences are the reasons why a certain attribute is important to the consumer. They are the psychological or physiological results that consumers think they can achieve by using the product or service (Gutman, 1982). Values are the consumers' universal life goals and the most personal and general consequences individuals are striving for in their lives (Rokeach, 1973).

Laddering usually involves personal semi-standardized in-depth interviews where the interviewer's probing questions are used to reveal attribute-consequence-value chains. Cognitive concepts gleaned during the laddering interviews are summarised in a graphical representation of a set of means-end 
chains known as a Hierarchical Value Map (HVM). An HVM, which is the key outcome of a laddering study, consists of nodes representing the most important attributes/consequences/values (conceptual meanings) and lines, which indicate links between concepts.

\section{Data collection}

\subsection{Sample size and characteristics}

The minimum sample size for laddering research is 20 respondents per subgroup as it provides a full range of attributes, consequences and values (Reynolds et al., 2001). According to Reynolds et al. (2001) each respondent provides at least five ladders, each of which includes five elements on average. Ladders from 20 interviews will thus include a minimum of 500 data points. Therefore, interviews with 20 bank employees (customer service officers who deal with customers both by appointment and on an ad hoc basis) and 20 customers of this bank were conducted to gain significant insights into customer and employee perceptions in the banking industry in a European country.

The first step in the sampling design process is to determine the sampling frame, a means by which elements of the population are represented. Commonly used sampling frames are telephone books and electoral rolls (Bryman and Bell, 2007). However for this study, it was not possible to obtain a confidential list of retail customers from the bank. As a consequence, a non-probability sampling technique was used to identify customer respondents. A technique which is considered to be useful for exploratory research (Malhotra and Birks, 2007) and that has been used successfully in similar service research recently (Groth et al., 2009) is snowball sampling. It consists of asking recruited respondents to refer subsequent participants that share the characteristics desired for the research (Malhotra and Birks, 2006). Employee respondents were selected by the management of the participating bank, which is the market leader in the country. 
The age of respondents ranged from 21 to 65 years with averages of 24.5 for the customer subgroup and 39.5 for the employee subgroup. Customers' years of patronage ranged from 1 year to 35 years, with an average of 12.75 years. Employees' years of employment ranged from 2 to 30 years, with an average of 14.1 years. Moreover, it was also attempted to maintain balance between the genders as a significant imbalance could otherwise have affected value preferences and thus distort the results (Rokeach, 1973). The sample characteristics are summarised below in table 1.

Insert Table 1 about here

\subsection{The laddering interview process}

Respondents were interviewed face to face; allowing them to speak freely about their experiences and feelings. The interview environment is argued to be important so that respondents are willing to provide insights into their underlying motivations and perceptions and talk freely about their service experiences (Reynolds and Gutman, 2001). Therefore, interviews with customers were conducted at their homes in order to make them feel as comfortable as possible. Similarly, employees were interviewed at their own desks or office in the bank, which can be seen as their comfort zone.

Before the laddering interviews began, the critical incident technique (CIT) was used as a "warmup" technique for the interview due to its ability to provide insight into customer experiences (Burns et al., 2000). Flanagan (1954, p. 327) defines CIT as "consisting of a set of procedures for collecting direct observations of human behaviour in such a way as to facilitate their potential usefulness in solving practical problems and developing broad psychological principles “. During CIT interviews, respondents are asked to tell a story about an experience which was either satisfying or dissatisfying (a critical incident) (Gremler, 2004). CIT has been used in previous studies in the area of service quality by 
assessing favourable and unfavourable incidents in service encounters from the customer and contact employee's point of view (Bitner et al., 1990, 1994; Johnston, 1995).

For the purpose of the present research study, respondents were asked at the beginning of each interview to talk about one of their satisfying service encounters with a frontline employee. CIT was used to create a frame of reference for the respondents, to show them that the researcher was genuinely interested in their experiences and to make them feel comfortable to answer succeeding questions (Gruber et al., 2009b).

The laddering interviews with customers and employees then started by asking them for sociodemographic information including, age and occupation. Employee respondents were then asked for theirs years of patronage/employment with the bank. Thereafter, customers were asked to elicit the attributes they expect from frontline employee during personal interactions: What are the main attributes you are looking for in a frontline employee while dealing with your request? The interviewer then tried to construct the chains of means-end relationships and helped the respondents climbing up the ladder of abstraction by asking: 'Why is that important to you?'; 'How does it help you out?'; 'What happens to you as a result of that?' (Reynolds and Gutman, 1988). The same procedure of probing was applied to frontline employees: 'What are the main attributes a customer is looking for in a frontline employee while dealing with his/her request? Every time a respondent provided an answer the interviewer then asked: 'Why do you think that is important for the customer?'; 'How does it help the customer out?'; 'What happens to the customer as a result of that?' Questioning continued until respondents reached the value level; gave repeating answers, or were simply not able or willing to provide an answer. In some cases, respondents were not able to proceed further and in this case it was important that the interviewer did not put words into the respondent's mouth or gave examples to the 
respondent to avoid obtaining biased responses (Reynolds et al., 2001). The interviewer would then go back to elicit another attribute.

If in some cases the respondent provided more than five attributes, the interviewer asked respondents to rank them in order of importance as suggested by Deeter-Schmelz et al. (2002) and probed from there. In situations when a respondent seemed unable to articulate the reasons why an attribute was important, negative laddering was employed (Reynolds and Gutman, 1988) by asking for example "What might be the effect if a contact employee did not have [attribute]?'”.

After each interview, respondents were asked to review the established ladders with the researcher in order to make sure that there was no misunderstanding of the concepts. According to Bryman and Bell (2007) member checking is a useful technique for qualitative research in order to enhance the credibility of findings. The interviews lasted between 20 and 60 minutes and were recorded for verbatim transcription used for the data analysis.

\section{Data analysis}

The laddering data were analysed in three stages (Reynolds and Gutman, 1988). First, content analysis was conducted in order to categorise and code the data from the laddering interviews. Content analysis is a data reduction process involving systematic techniques which are used to analyse the informational contents of textual data (Forman and Damschroder, 2008).

In order to develop a coding scheme each interview transcript was examined carefully. The process of coding hereby helps to eliminate irrelevant responses from the interviews (Miles and Huberman, 1994). The decision-support software programme LADDERMAP (Gengler and Reynolds, 1993) was used for this purpose as it allowed entry of up to ten chunks of meaning per ladder and the categorization of each phrase as either an attribute, consequence or value. Coding was an iterative exercise of recoding data, splitting, combining categories, generating new or dropping existing 
categories. The coding process produced meaningful categories to group together phrases with identical meanings. The identification of categories was through phrases and key words that respondents used during the interviews and from concepts derived from the literature review.

The following tables display the 22 attributes, 24 consequences and 9 values which resulted from the 40 interviews. The table provides a short description of each construct, reference to similar concepts in the literature and the number of times the concepts were mentioned by each subgroup. The codes are listed in alphabetical order.

Insert Tables 2-4 about here

Second, the codes for individual means-end chains had to be aggregated across subjects and illustrated in an implication matrix to express the number of associations between the conceptual meanings (attributes/consequences/values). This implications matrix details the associations between the constructs and acts as a bridge between the qualitative and quantitative elements of the technique by showing the number of times one code leads to another (Deeter-Schmelz et al., 2002). The numbers to the left of the decimal show the direct relations that an element has to another, while the number on the right shows the total amount of direct and indirect relations (Gruber et al., 2006). For example in the extract of the implicaiton matrix from customers shown below (Table 5), "responsive" leads to "save time" 11 times directly and zero times indirectly (11-11). Therefore, 11 respondents associated employees when being responsive as direclty saving their time and there were no indirect linkages between these two concepts.

Insert Table 5 about here 
Finally, two HVMs were generated: one for employees and one for customers. Gengler et al. (1995, p. 245) define a HVM as "a graphical representation of a set of means-end chains which can be thought of as an aggregate (e.g., market-level) cognitive structure map". The map consists of nodes, which stand for the most important attributes/consequences/values (conceptual meanings) and lines, which represent the linkages between the concepts. The map graphically sums up the information collected during the laddering interviews (Claeys et al., 1995) and normally consists of three different levels, which relate to the three concepts of meaning.

In order to make the maps interpretable a balance between data reduction and retention had to be achieved by specifying a so-called "cut-off” level (Gengler et al., 1995). The cut-off level of four was determined for both subgroups as it was considered to depict the most important constructs and not eliminating any relevant information; maintaining thus the balance between interpretability and detail (Christensen and Olson, 2002). The cut-off level of four means that respondents had to mention linkages between concepts at least four times for concepts to be graphically represented in the maps (Gengler et al., 1995). In addition, the information presented in the map had to be structured by placing the values at the top of the HVM map, whereas consequences were positioned near the middle and attributes at the bottom of the maps. The size of the circles indicates the relative frequency mentioned by the respondents. The thickness of the lines between concepts shows the strength of the relationship.

\section{Results and discussion}

\subsection{The customer perspective}

The HVM reveals a complex structure. The attribute most desired by customers is "friendliness", which was mentioned by 14 participants. It leads to the most important consequence, to establish trust in employees ("trust"). The consequence "trust" was mentioned 18 times. In addition, the consequences of friendliness are also to create a connection with employees ("rapport"), to feel comfortable in the bank 
("comfort"), and it is also considered as an attribute that is taken for granted ("meet expectations").

"Rapport" is then linked to the values "happiness" and "feel good".

Insert Figure 1 about here

The second two most important attributes for customers are employees who are "responsive" and competent ("competence"). Responsiveness is one of the five determinants of service quality in the SERVQUAL scale (Parasumaran et al., 1988), whereas competence was conceptualised as one of the 10 dimensions that customers use in forming perceptions of service quality (Parasumaran et al., 1985). Similarly, Zeithaml et al. (1988) argue that employees' knowledge of the company's offering is critical in order to close possible pitfalls in the sevice delivery. Competence or expertise is also conceptualised as one of the primary dimensions in the service quality model proposed by Brady and Cronin (2001). Findings from previous studies in banks indicate that friendliness and competence are two major factors influencing customer satisfaction with bank employees (Surprenant and Solomon, 1987).

Customers associate employees' "competence" as solving their request ("solution") which has a strong link to customers' desire to feel safe ("security"). The attributes "competence" and "responsive" will allow customers to save their time ("save time"). "Save time" is direclty linked to "satisfaction" and "happiness" and indirectly linked to "hedonism". Being "responsive" leading to "save time" and then leading to "happiness" and "hedonism" represents one of the most dominant paths in the value map. In particular, as the width of the linkage indicates, as customers can save their time ("save time"), it allows them to devote attention to other issues ("concentrate on other issues"). By being able to focus on other issues customers can enjoy life ("hedonism").

In additon, being flexible, meaning that employees should be less strict with regulations ("flexibility"), allows customers also to "save time". To our best knowledge, "flexibilty" in the sense of 
being less strict with regulations has so far not been proposed as a desired attribute of frontline employees in order to create a successful service encounter. So far, the concept of flexibilty, which is considered to be an important criteria of perceived service quality (e.g. Armistead, 1990; Bearden et al., 1998; Gwinner et al., 2005), has been defined as either customising the service or adding addtional service components.

To "save time" was also mentioned to give customers the feeling that their needs are being understood ("feel understood"), which makes them feel important and valued by employees ("selfesteem"). The consequence "feel understood" is also evoked by employees" "communication skills".

The main consequence "trust" is strongly influenced by employees being honest ("honesty") and "reliable". Customers think that if they can "trust" the employees, they will stay with the bank ("loyalty") and achieve the feeling of being safe and secure ("security"), which is the most important value customers aim to satisfy (mentioned 16 times).

For customers in order to be able to feel secure ("security") customers need to feel that they have "assurance" and "control". The consequence "control" leads hereby back to the employees' ability to advise the customer ("advice") and to be "informative". With employees being "informative" customers can understand the service and product provided ("gain knowledge"), which is crucial for them. As the width of the line in the HVM reveals, "control" is strongly linked to the value of "security".

By addressing customers with their name ("know customer's name") it seems to be very important for them to feel as being treated like individuals ("treated as individual") which makes them feel personally connected to employees ("rapport") and ultimately makes them feel happy ("happiness") and "feel good". Being "treated as individual" also makes customers feel more comfortable ("comfort") during the service encounter. If employees are "polite" customers also feel more comfortable ("comfort"). 
According to the HVM, customers in particular want to satisfy the following values: "security" (which was mentioned 16 times), "happiness" (14 times), "feel good" (10 times), "satisfaction" (8 times), "hedonism" (7 times), and "self-esteem" (6 times).

\subsection{The employee perspective}

The HVM for employees reveals that employees perceive that the attribute most desired by customers is good "communication skills", which was mentioned by 13 respondents. "Communication skills" is an important attribute that supports findings from the sales management literature which suggest that the contact employee's communication skills play an important role for personal interactions (DeeterSchmelz et al., 2002; Ramsey and Sohi, 1997). The employee's ability to communicate effectively with customers has been found as an important factor in banks (Surprenant and Solomon, 1987). Together with "friendliness" (mentioned 12 times) it makes customers feel that they can speak freely with employees about their needs (“open up"). Employees believe that when customers can "open up", customers can easier establish a relationship with employees.

Insert Figure 2 about here

"Trust" is strongly related by employees to the concept "relationship". Even though the map shows a strong link between "honesty" and "trust", the latter is also perceived to be attainable by being "reliable". Being able to "trust" employees is strongly linked to the ability to build a "relationship" with employees and this ultimately makes customers feel safe ("security). By addressing customers with their name ("know customer's name") and through the establishment of "rapport", employees perceive that customers also feel more comfortable ("comfort") and are then satisfied ("satisfaction") with the service provided. 
However, the strongest path in the map links "know customer's name" to "rapport", then to "relationship" and ultimately to the value of "security". Employees consider building a "relationship" as the most important consequence (mentioned 17 times) which is most strongly associated with customer needs of "security". When employees are able to show that they care of and show interest in customers ("empathy"), customers are eager to have a "relationship" with employees. According to employees the establishment of a "relationship" directly makes customers "feel good". By being in a "relationship" customers stay loyal ("loyalty"), which is directly linked to the feeling of being important to the bank (self-esteem) and indirectly linked to "happiness" and "satisfaction". It has also been argued in the literature that social skills such as empathy have a strong influence on customer satisfaction and retention, hence facilitating relationship building (Donavan et al., 2004; Hennig-Thurau, 2004).

The attribute "patient" has been identified by employees as leading to the consequence of providing customers a "solution", which is directly linked to the feelings of "happiness" and "security". However, being "patient" was strongly related by employees to the feeling that customer needs are being understood . The feeling of understanding ("feel understood") makes customers feel safe ("security") and customers stay loyal with the bank ("loyalty"). "Loyalty" then is directly linked to feeling important and valued by the bank ("self-esteem"). Moreover, by being loyal ("loyalty"), employees perceived that customers will positively speak about the bank ("word-of-mouth") which is leading to "happiness" and "satisfaction". Similarly, Bowen and Lawler (1995) argue that satisfied customers are not only loyal, but they also generate positive word-of-mouth. Employees also consider that when customers are loyal ("loyalty"), they are willing to pay more ("price premium"), leading then to "satisfaction".

The attribute "competence" has been identified by employees as not only leading directly to "loyalty" but most importantly to the consequence of having a "solution", to know that employees will fulfil customer requests, which is strongly linked to the feeling of "happiness and "security". Moreover, 
the attribute of being "responsive" gives customers not only the opportunity to "save time", but is strongly linked to "solution". Responsiveness, reliability and empathy have not only been conceptualised as important dimensions of the SERVQUAL scale (Parasuraman et al., 1988), but have also been confirmed by several studies conducted in the banking industry as being important in customers' evaluations of service quality (Barger and Grandey, 2006; Bedi, 2010).

Employees also strongly believe that when they are dressed well ("well presented"), customers will be more assured that their request will be handled professionally ("assurance"). Once customers feel assured they have the feeling of certainty and security ("security"). In addition, "assurance" leads to "solution", which is also evoked by "greater effort" shown by employees. "Solution" is then directly linked to "satisfaction", but most importantly to the values "happiness" and "security". Providing customer with assurance was identified by Parasuraman et al. (1988) as one of the five determinants for service quality. In the literature it has been recognised that employees' appearance influences customers' perceptions of service quality in banks (Baron and Harris, 2003).

According to employees, customers in particular want to satisfy the following values: "security" (which was mentioned 18 times), "satisfaction" (18 times), "feel good" (13 times), "happiness" (13 times), and "self-esteem" (9 times).

\subsection{Comparison of customer and employee perspectives}

The two complex HVMs (Figures 1 and 2) show that both subgroups identify many of the same attributes, consequences and values. It also confirms the premise that employee behaviours and attitudes determine the evaluation of service encounters and thus shape customers' perceptions of service quality. However, there are several concepts which only appear in one of the HVMs, and some attributes identified by customers and employees are leading to different consequences and end-values. 
In terms of similarities, employee characteristics such as friendliness, competence, responsiveness, honesty and communication skills were identified by both groups. These results corroborate previous research findings in banks that friendliness, responsiveness and competence are key attributes in shaping customer perceptions of service quality (e.g. McCullough, 1993; Schneider and Bowen, 1985;

Surprenant and Solomon, 1987). In addition, both parties agreed on the importance of trust for customers. As suggested by Shemwell et al. (1994), the concept of trust is one of the fundamental elements in order to evaluate service quality. Similarly, Johnston $(1995 ; 1997)$ argues that especially in the banking sector honesty, justice and fairness are fundamental for customers in order to maintain trust in the employee. Both customer and employee respondents agreed on the necessity of employees being reliable and honest in order to establish trust and to satisfy customers' need to feel secure in the bank.

Security was identified by both parties as being one of the major values customers want to attain. This can be attributed to the nature of the financial service and its attached importance, but also to its complexity and high uncertainty for customers.

However, there are differences in the importance of trust and in the consequences mentioned around trust. Especially for customers establishing trust in employees seems to be the key for a successful service experience leading to increased loyalty with the service provider. Conversely, the findings from this study with customers contest findings by Shemwell et al. (1994) that the ability to engender trust between customers and employees will result in a relationship. Employees on the other hand established the link between trust and relationship development. This finding suggests that employees perceived trust as an important antecedent for a successful relationship, whereas customers did not (Morgan and Hunt, 1994). Moreover, customers directly linked trust to becoming loyal to the bank which leads to the desired end-state of security. This finding is in line with previous studies in banks that the development 
of trust between customers and contact employees are important antecedents of customer loyalty in retail banking (Lewis and Soureli, 2006).

Another important concept mentioned by both parties is the creation of rapport during the service encounter. The results from the employees' interviews corroborate previous research findings that rapport is an important antecedent for developing a relationship and can positively influence customer satisfaction, loyalty and word-of-mouth recommendation (Price and Arnould, 1999; Pullman and Gross, 2004). However, from the customers' point of view findings indicate that the establishment of rapport with employees is leading to the desired end states of feeling good and being happy. It is surprising that although the concept relationship was mentioned during the interviews with customers, it is not linked to rapport and does not appear at all in the HVM.

Nevertheless, both parties agreed that in order to create rapport with customers, employees need to use the customer's name. However, customers mentioned that the feeling of having a personal connection with the employee can only be created if they feel that employees are treating them like individuals, not like numbers. This implies that only knowing customer's name is not enough for customers. Employees thus need to be personal during the service encounter and be able to relate to customers at a human level. Only when this interest is shown customers are willing to talk about their personal interests and create a personal connection with the employee. In the literature, personalisation has been proposed by Mittal and Lassar (1996) as the most important determinant of perceived service quality for companies with high interactive service encounters.

The employees' ability to be responsive during the service encounter was mentioned in both subgroups, enabling customers to save time. However, the consequence of saving time was less significant from the employee perspective, whereas for customers the opportunity of saving their time was highly emphasised during the interviews. As can be seen from the customers' HVM saving time is 
the second most important consequence for customers as it leads to the end values of not only being satisfied with the service provided, but also being happy and able to enjoy life. Customers feel that if they can save time in the bank, they can use it in order to focus on other issues, thus in the end enjoy their life more. However, customers' need to concentrate on other issues and this consequence leading to the desired end-state of hedonism do not appear in the employees' HVM. The two concepts have not been mentioned at all during the interviews with employees. On the contrary, employees identified their abiltiy to be responsive as providing customers a solution and hence making them happy and feel secure.

A similar finding was found for competence as it has been mentioned by customers as saving their time, giving them the opportunity to spend their time on other issues and reinforcing their desired values of pleasure and happiness. Employees on the other hand linked competence to the ability of providing customers a solution and thus leading to the end-states security and happiness. Customers also identified that employees providing them a solution will make them feel safe. In addition, employees implied that their competence will increase customer loyalty, and then increase customers' need of self-esteem. Customer loyalty was also linked to positive word-of-mouth and customers ' need to be happy and satisfied with the service provided. According to employees, loyal customers are also willing to pay a higher price or higher interest rates compared to competitors if they are satisfied with the service provided. However, these constructs around loyalty have not been established by customers as described above.

Further, to be informative and to give advice seems to be of relative importance to customers, but they do not appear in the employees' HVM. Customers expect employees to be willing to answer questions, explain procedures and inform customers about changes in their accounts. They appreciate employees being eager to share information with them. Advising customers so that they can make the right decision gives customers the feeling of control as they need to be certain of making the right 
decision in order to feel safe. Customers' perceived control has been discussed in the literature as an important dimension for a successful service experience (Bitran and Hoech, 1990; Czepiel et al., 1985). The perception of having control and making the right decisons are strongly linked for customers to reinforce their security values. Conversely, the findings seem to point out a fragmentation in the way customers want to gain the feeling of security. On the one hand, customers want to have the feeling of control and make their own decisions but on the other hand customers seem to appreciate employees providing them with a solution. Employees on the other hand identified providing customers with a solution as one of the most important consequences for customers. Furthermore, employees identified their appearance as providing customers with the assurance that their request will be handled professionally, which gives customers the feeling of security. This attribute however does not seem to be of importance to customers, since it has only been mentioned once in the interviews.

In addition, the two most important attributes identified by employees, their ability to know how to interact and communicate with customers together with being friendly have been linked to the consequence that customers will be able to speak freely with the employees about their needs and thus enhance relationship building. Customers' possibility to open up has been identified as the second most important consequence for customers as can be seen in the employees' HVM. The concept of open up is however not shown in the customers' HVM and thus seems to be of less importance for customers.

Customers therefore imply good communication skills as giving them the feeling of being understood by the employees which will then enable them to save their time. Moreover, customers agreed that if employees are less strict with regulations, they have more time for other issues that are important to them, and it thus gives them the chance to enjoy life more. Saving time leads to customers' desired endstates of happiness and satisfaction. The attribute flexibility has not been mentioned at all during the interviews with employees, as this would imply that employees do not follow the code of conduct of the 
bank. Not following the regulations could have negative consequences for employees such as the termination of employment.

Regarding the customers' desired end-states from the service encounter, it can be concluded that customers and employees identified similar values, however their importance seem to differ. Both subgroups identified security as the main value which can be attributed to the nature of the banking service and thus customers' sensation linked to feeling in safe hands, secure and protected (Maslow, 1959). Customers then value happiness and feeling good, followed by satisfaction. Employees in contrast identified satisfaction together with security as the main values for customers, followed by happiness and feeling good. The value hedonism emerged as an important value from the customer perspective of a successful service encounter. Hedonism was however not mentioned at all in the interviews with employees. Therefore, it is suggestive that employees consider customer satisfaction as more important for a successful service encounter rather than customer feelings of being happy, feeling good and their needs to enjoy life. It can thus be argued that customers aim to satisfy personal values such as happiness and pleasure (Rokeach, 1973) and that satisfaction might only be of secondary importance to them. Employees on the other hand tend to take a more rational view, with a focus on the satisfaction of customer needs.

\section{Contribution of study and managerial implications}

The present research findings reveal customers' and employees' perceptions regarding a successful service encounter in the retail banking sector. The findings present the customers' desired attributes and behaviour of employees. The major contribution of this research lies in its dyadic approach by comparing both perspectives of the service encounter in a bank setting. The study thus provides a first insight into the expectations of employee behaviour by identifying the desired attributes and linking these to consequences and values. Although previous service quality research in the banking industry 
and other industries has arrived at similar findings, none of them have attempted to examine what lies behind the attributes "friendliness", "responsiveness" or "competence" that customers ask for and the values customers want to achieve during the service experience. Moreover, none of these studies applied a dyadic approach which is the focus of this exploratory research study. Another strong contribution of this paper is the finding that all the identified concepts from the laddering interviews that are shown in the HVMs must not been seen in strict isolation, as in previous research, but have to be understood as a network of interrelated concepts.

Findings from this study can be used by employees and management in order to improve perceived service quality in the service industry, and particularly in retail banking. In particular, the implications arising from this study point towards a careful management of the service encounter as it is critical to focus on the development of the customer-employee relationship in order to create value for customers and the bank. Since interactions between customers and employees are determinant for value creation, it is argued that value can only be co-created with the customer (Edvardsson et al., 2005; Vargo and Lusch, 2004).

The study points out that frontline employees need to be friendly and show a genuine interest not only for customer needs but also in the customer as a person in order to create rapport. Employees thus need to carry out emotional labour as they need to adapt and control their emotions so that it is appropriate for any given situation (Hochschild, 1983). They do not only need to show empathy, but also a genuine concern for customer needs and their feelings, which supports recent findings by Gruber (2011). It can thus be concluded that customers do not only want employees to smile, be friendly, but also to engage with them. Engaged employees have been recognised as the most important factor influencing the customer experience (Pine and Gilmore, 1999; Schmitt, 1999). Various researchers argue that managers and customers' expectations to fulfil emotional labour can cause stress in 
employees, which can then negatively impact the service encounter (e.g. Blake and Humphrey, 1993; Hochschild, 1983; Kruml and Geddes, 2000). It is therefore important that employees learn how to manage their feelings and learn how to cope with stress. Socialisation programmes and seminars can hereby help to provide guidelines to employees on how to behave during the service encounter, and thus reduce role ambiguity and stress levels (Singh, 1993). This will then have a positive impact on customers' evaluations of the service encounter.

Moreover, it is imperative to identify and recruit contact employees who are genuinely interested in their job, care about customers and put every effort to satisfy customer needs and make them happy. Employees should attempt to get to know the customer as a person and be able to interact with personal warmth. This study shows that customers wish to create rapport with employees and be treated as individuals. Hence, it is important not only to recruit people who have product or service expertise, but also people with strong social skills (Donavan et al., 2004). Companies should especially recruit employees who show genuine concern for their customers or at least are very skilled at giving the impression of being interested in their customers' concerns (Gruber, 2011).

The findings of this study also indicate to recruit people who can build customer relationships. It also shows that the relationship concept has not been considered as an important component from the customer point of view. Since relationships are positively related with customer satisfaction, loyalty and positive word-of-mouth (Price and Arnould, 1999; Pullman and Gross, 2004), employees need to foster relationship building with customers. However, employees have to consider that the creation of a relationship depends on both sides and implies the customer's willingness to open up and to share information. As pointed out in the literature the creation of rapport is the first step for a successful relationship with customers (Gremler and Gwinner, 2000). Customers therefore need to be aware of the direct benefits of entering into a relationship with the service provider. This can be done by showing 
customers that a relationship can help them to establish trust, as trust was identified as being crucial in order to gain the feeling of security. Trust has been highly recognised in the literature as an effective element for establishing a successful relationship (e.g. Swan et al., 1999; Tam and Wong, 2001). In addition, in order to nurture and maintain trust, employees need to be honest, and not hide any details about service charges or interest rates.

Furthermore, customers want to get advice from employees and share information with them. Customers want to have the feeling of control during the service process and make the right decision. They thus want to be integrated in the service provision. Therefore, employees need to understand that customers do not only want to be provided directly with a solution, but they want to be actively involved in the service offering. Value can thus only be created in interaction with customers and they need to be considered as active players during the service encounter (Vargo and Lusch, 2004). According to service-dominant logic, the ability to share information hereby relies on mutual trust between the parties and is essential for the co-creation process (Vargo, 2008).

Due to the fact that responsiveness has been identified as an important employee characteristic in this study, the need for empowerment has to be recognised by management, in order to deal efficiently with customers and help them save time (Holmlund and Kock, 1996; Rafiq and Ahmed, 1998).

Empowerment allows employees to deal with customers efficiently and it is argued that empowerment is vital for service companies that require face-to-face contact between customers and frontline employees (Baron and Harris, 2003; Boshoff and Leong, 1998).

According to Bowen and Lawler (1992; 1995) empowered employees need to have information about the company's performance and knowledge on how to contribute to business processes and performance. Power needs to be redistributed within the organisation by pushing down decision-making to employees in order to give employees the opportunity to respond fast to customers' requests. Rafiq 
and Ahmed (1998) posit that responsiveness, assurance and empathy are service quality dimensions which are highly dependent on the employees. The authors further assert that the higher the expected level of these dimensions from the customer point of view, the greater the need for empowerment. Similarly, Holmlund and Kock (1996) argue that empowerment in retail banking must be implemented in order to give employees the power to fulfil their job requirements and to satisfy their customers.

The high importance for customers of saving time has hereby to be more emphasised by management. Employees therefore need to understand that saving time does not only satisfy customers, but simultaneously makes them happy and gives them the opportunity to enjoy life. Employees need to be aware of the fact that customers do not only aim to satisfy their functional needs; but they also want to have their personal values and needs satisfied (hedonism and happiness).

The literature strongly suggests that service companies should use internal marketing in order to provide good service quality to their customers. Therefore, with an internal marketing programme, banking institutions can not only help to improve internal communications, but also motivate employees and create a sense of belonging, which on the other hand will foster relationship building (Richardson and Robinson, 1993; Tortosa et al., 2009). They thus need to nurture customer orientation among service employees, which can be built through on-the-job-training, continuous evaluation of employee performance and formal training programmes (Kelley, 1992). Moreover, management should not only provide feedback to their employees but also establish performance evaluations, based on which training programmes can be designed (Kelley, 1992). This will then help employees to improve their competences.

Furthermore, constant training about the service and products provided is crucial, in order to fulfill customers' expectations of dealing with competent front-line employees. In particular, customers expect employees to have sufficient knowledge about the product and to know the bank's procedures. This 
reflects the work of Becker and Wellins (1990) who found that customers want employees to have an understanding of the company's products, proecdures and policies releated to the the service provided.

This study also reveals that managers need to be aware of the fact that employees are not always impartial and do not always provide equal treatment to their customers. The findings indicate that employees not always strictly follow company rules, since customers identified flexibility as an employee characteristic. These actions could have implications on the value effects of the bank and thus need further examinations. Another issue to be taken into account by management is the identified discrepancy in perceptions regarding word-of-mouth and price premium.

In addition, the results of this study provide ideas for banking institutions for the development of their brands by shedding lights on the values and benefits that are important to customers. The meansend approach has originally been used to help to identify positioning strategies for products (Reynolds and Gutman, 1988). Hence, when defining their brand identity, banking institutions can focus on aligning it with the benefits and values sought by their customers. Moreover, since employees are described in the marketing literature as 'brand's ambassadors' (Harris and De Chernatony, 2001), their behaviours determine the service experience and thus the values associated by customers with the company brand. Therefore, managers need to clearly communicate the brand's purpose to employees and help them to understand how their roles relate to it.

To conclude, by recruiting employees with the desired employee characteristics, providing them with intensive training and treating them as internal customers, the satisfaction of frontline employees can be increased who can then deliver an excellent service to their customers and also enhance customer loyalty (Heskett et al., 2008). Moreover, the overarching focus on service quality can only be established with a focus on building a strong service culture, including every employee in the organisation, hence 
creating a successful service brand (Brown, 2003). A successful service brand is lived internally by every employee of the organisation and then translated to its customers through the service experience.

\section{Limitations and directions for further research}

This study was explorative in nature as it was the first dyadic study using the laddering technique in a retail banking setting. Although the results provide rich insights, the study also presents some limitations related to its methodology. These limitations, however, can provide a starting point for further research.

First, it would be worth to investigate whether there are differences in customers' desired attributes of long-term customers compared to new customers of the bank. The sample in this study was also constrained to one bank, which implies to take caution when interpreting the results.

Although results obtained from laddering studies based on the means-end approach permit an understanding of customer's underlying motivations with respect to a particular product class, service or individual, a means-end approach alone cannot explain or predict behaviour (Reynolds and Gutman, 2001). A means end chain could thus be included or compared with existing consumer behaviour theories such as the theory of reasoned action (Grunert et al., 2001). In addition, there is neither any theory nor statistics that assist the researcher in deciding on the cut-off levels for the creation of the HVMs (Reynolds and Gutman, 2001). Therefore, further research should address these issues.

The study involved customer service officers. The results could be different if cashiers who help identify and meet the day-to-day needs of customers and perform basic financial transactions would have been interviewed as they have only short interactions with customers.

As findings from this study indicate that customers expect employees to be less strict with regulations, future research should examine the possible value effects for the bank. Moreover, more research using a dyadic approach should be conducted in order to compare customers' and employees' 
perceptions of the concepts price premium and word-of-mouth as new insights might have an impact on the company's external communication strategy.

What is needed now are more dyadic studies or even a triadic approach as proposed by Svensson (2006) by including the management perspective that would not only provide a deeper perspective of the service quality construct, but also capture the inherent complexities and dynamics of the creating satisfying service encounters in retail banking. 


\section{References}

Allen, J., Reichheld, F.F., Hamilton, B. and Markey, R. (2005) 'Closing the delivery gap - How to achieve true customer-led growth', available at:

http://www.bain.com/bainweb/PDFs/cms/Public/BB_Closing_delivery_gap.pdf [accessed 12 July 2011].

Armistead, C.G. (1990) 'Service operations strategy: Framework for matching the service operations task and the service delivery system', International Journal of Service Industry Management, Vo1.1, No. 2, pp.6-17.

Barger, P.B. and Grandey, A.A. (2006) 'Service with a smile and encounter satisfaction: Emotional contagion and appraisal mechanisms', Academy of Management Journal, Vol. 49, No. 6, pp.12291238.

Barnes, G.B. (1997) 'Closeness, strength and satisfaction: Examining the nature of relationships between providers of finanical services and their retail customers', Psychology and Marketing, Vol. 14, No. 8, pp.765-87.

Baron, S. and Harris, K. (2003) Services Marketing - Text and Cases. 2nd ed, Palgrave, Basingstoke.

Bearden, W.O., Malhotra, M.K. and Uscátgui, K.H. (1998) 'Customer contact and the evaluation of service experiences: Propositions and implications for the design of services', Psychology and Marketing, Vol. 15, No. 8, pp.793-809.

Beaujean, M., Pereira, F.G. and Schuler, U. (2007) Creating Value Through Customer Insights, Ulrich Scholz Design, Düsseldorf.

Becker, W.S. and Wellins, R.S. (1990) 'Customer service perceptions and reality’, Training and Development Journal, Vol. 44, No. 3, pp.49-51.

Bedi, M. (2010) 'An integrated framework for service quality, customer satisfaction and behavioral responses in Indian banking industry - A comparision of public and private sector banks', Journal of Services Research, Vol. 10, No. 1, pp.157-72.

Berry, L.L. and Parasumaran, A. (1991) Marketing Services - Competing Through Service Quality, The Free Press, New York.

Bitner, M. J. (1995) 'Building service relationships: It's all about promises', Journal of the Academy of Marketing Science, Vol. 23, No. 4, pp. 246-251.

Bitner, M.J. and Brown, S.W. (2008) 'The service imperative', Business Horizons, Vol. 51, pp.39-46. 
Bitner, M.J., Booms, B.H. and Tetreault, M.S. (1990) 'The service encounter: Diagnosing favorable and unfavorable incidents', Journal of Marketing, Vol. 54, January, pp.71-84.

Bitner, M.J., Booms, B.H. and Mohr, L.A. (1994) 'Critical service encounters: The employee's viewpoint', Journal of Marketing, Vol 58, October, pp.95-106.

Bitran, G.R. and Hoech, J. (1990) 'The humanization of service: Respect at the moment of truth', Sloan Managment Review, Vol. 31, No. 1, pp.89-96.

Blake, E.A. and Humphrey, R.H. (1993) 'Emotional labor in service roles: The influence of identity', The Academy of Management Review, Vol. 18, No. 1, pp.88-115.

Boshoff, C. and Leong, J. (1998) 'Empowerment, attribution and apologising as dimensions of service recovery: An experimental study', International Journal of Service Industry Management, Vol. 9, No. 1, pp.24-47.

Botschen, G., Thelen, E.M. and Pieters, R. (1999) 'Using means-end structures for benefit segmentation', European Journal of Marketing, Vol. 33, No. 1/2, pp.38-58.

Bowen, D.E. and Lawler, E.E. (1992) 'The Empowerment of service workers: What, why, how, and when', Sloan Management Review, Vol. 33, No. 3, pp.31-39.

Bowen, J.W. and Hedges, R.B. (1993) 'Increasing service quality in retail banking', Journal of Retail Banking, Vol. 15, No. 3, pp.21-28.

Bowen, D.E. and Lawler, E.E. (1995) 'Empowering service employees', Sloan Management Review, Vol. 36, No. 4, pp.73-84.

Brady, M.K. and Cronin, J.J. (2001) 'Some new thoughts on conceptualizing perceived service quality: A hierarchical approach', Journal of Marketing, Vol. 65, July, pp.34-49.

Broderick, A.J. (1999) 'Role theory and the management of service encounters.', The Service Industries Journal, Vol. 19, No. 2, pp.117-31.

Brown, S.W. (2003) 'The employee experience', Marketing Management, March/April, pp.12-13.

Bryman, A. and Bell, E. (2007) Business Research Methods, 2nd ed., Oxford University Press, New York, NY.

Burgess, S.M. and Steenkamp, J.E.M. (1999) 5 Value Priorities and Consumer Behaviour in a Transitional Economy, Kluwer Academic Publishers, London.

Burns, A.C., Williams, L.A. and Maxham, J. (2000) 'Narrative text biases', Qualitative Market Research: An International Journal, Vol. 3, No. 4, pp.178-86. 
Chandon, J., Leo, P. and Philippe, J. (1997) 'Service encounter dimensions - A dyadic perspective:

Measuring the dimensions of service encounters as perceived by customers and personnel', International Journal of Service Industry Management, Vol. 8, No. 1, pp.65-86.

Christensen, G. and Olson, J. (2002) 'Mapping consumers' mental models with ZMET', Psychology and Marketing, Vol. 19, No. 6, pp.477-501.

Claeys, C., Swinnen, A. and Abeele, P.V. (1995) 'Consumers' means-end chains for 'think' and 'feel' products', International Journal of Research in Marketing, Vol. 12, pp.193-208.

Cronin, J.J. and Taylor, S.A. (1992) 'Measuring service quality: A reexamination and extension', Journal of Marketing, Vol. 56, July, pp.55-68.

Czepiel, J.A., Solomon, M.R. and Surprenant, C.F. (1985) The Service Encounter: Managing Employee/Customer Interaction in Service Businesses, Lexington Books, Lexington, MA.

Deeter-Schmelz, D. R., Kennedy, K. N. and Goebel, D. J. (2002) 'Understanding sales manager effectiveness - Linking attributes to sales force values', Industrial Marketing Management, Vol. 31, No. 7, pp. 617-626.

Deeter-Schmelz, D. R., Goebel, D. J. and Kennedy, K. N. (2008) 'What are the characteristics of an effective sales manager? An exploratory study comparing salesperson and sales manager perspectives', Journal of Personal Selling \& Sales Management, Vol. 28, No. 1, pp. 7-20.

Donavan, D.T., Brown, T.J. and Mowen, J.C. (2004) 'Internal benefits of service-worker customer orientation: Job satisfaction, commitment, and organizational citizenhship behaviors', Journal of Marketing, Vol. 68, January, pp.128-46.

Edvardsson, B., Gustafsson, A. and Roos, I. (2005) 'Service portraits in service research: A critical review', International Journal of Service Industry Management, Vol. 16, No. 1, pp.107-21.

Fisk, R.P., Brown, S.W. and Bitner, M.J. (1993) 'Tracking the evolution of the services marketing literature', Journal of Retailing, Vol. 69, No. 1, pp.61-103.

Flanagan, J. (1954) 'The critical incident technique', Psychological Bulletin, Vol. 51, No. 4, pp.327-58.

Forman, J. and Damschroder, L. (2008) 'Qualitative content analysis', Advances in Bioethics, Vol. 11, pp.39-62.

Gengler, C.C., Klenosky, D.B. and Mulvey, M.S. (1995) 'Improving the graphic representation of means-end results', International Journal of Research in Marketing, Vol.12, pp.245-56.

Gengler, C.E. and Reynolds, T.J. (1993) Laddermap. [Computer Software]. 
Goodwin, C. and Smith, K. (1990) 'Courtesy and friendliness: Conflicting goals for the service provider?', Journal of Services Marketing, Vol. 4, No. 4, pp.5-20.

Greene, W.E., Walls, G.D. and Schrest, L.J. (1994) 'Internal marketing - The key to external marketing success', Journal of Services Marketing, Vol. 8, No. 4, pp.5-13.

Gremler, D.D. (2004) 'The critical incident technique in service research', Journal of Service Research, Vol. 7, No. 1, pp.65-89.

Gremler, D.D. and Gwinner, K.P. (2000) 'Customer-employee rapport in service relationships', Journal of Service Research, Vol. 3, No. 1, pp.82-104.

Grönroos, C. (2007) Services Managment and Marketing - Customer Management in Service Competition, 3rd ed, John Wiley, Southern Gate.

Groth, M., Hennig-Thurau, T. and Walsh, G. (2009) 'Customer reactions to emotional labor: The roles of employee acting strategies and customer detection accuracy', Academy of Management Journal, Vol. 52, No.5, pp. 958-974.

Grove, S.J., Fisk, R.P. and John, J. (2003) 'The future of services marketing: Forecasts from ten services experts', Journal of Services Marketing, Vol. 17, No. 2, pp.107-21.

Gruber, T. (2011) 'I want to believe they really care - How complaining customers want to be treated by frontline employees', Journal of Service Management, Vol. 22, No.1, pp. 85-110.

Gruber, T. and Frugone, F. (2011) 'Service recovery in health services - Understanding the desired qualities and behaviours of general practitioners (GPs) during medical (service recovery) encounters', Journal of Service Management, Vol. 22, No. 4, pp. 491-521.

Gruber, T., Szmigin, I. and Voss, R. (2006) 'The desired qualities of customer contact employees in complaint handling encounters', Journal of Marketing Management, Vol. 22, No. 5-6, pp. 619-642.

Gruber, T., Szmigin, I. and Voss, R. (2009a) 'Handling customer complaints effectively - a comparison of the value maps of female and male complainants', Managing Service Quality, Vol. 19, No. 6, pp. 636-656.

Gruber, T., Szmigin, I. and Voss, R. (2009b) 'Developing a deeper understanding of attributes of effective customer contact employees in personal complaint handling encounters', Journal of Services Marketing, Vol. 23, No. 6, pp. 422-435.

Grunert, K.G., Beckmann, S. C. and Sørensen, E. (2001) 'Means-end chains and laddering: an inventory of problems and an agenda for research', in Reynolds, T. J. and Olson, J. C. (Eds.), Understanding 
Consumer Decision Making - The Means-End Approach to Marketing and Advertising Strategy, Lawrence Erlbaum Associates, Mahwah, NJ, pp. 63-90.

Gutman, J. (1982) 'A means-end chain model based on consumer categorization processes', Journal of Marketing, Vol. 46, No. 2, pp. 60 - 72.

Gwinner, K.P., Bitner, M.J., Brown, S.W. and Kumar, A. (2005) 'Service customisation through employee adaptiveness', Journal of Service Research, Vol. 8, No. 2, pp.131-47.

Harris, F. and De Chernatony, L. (2001) 'Corporate branding and corporate brand performance', European Journal of Marketing, Vol. 35, No. 3/4, pp.441-56.

Hartline, M. D. and Ferrell, O. C. (1996) 'The management of customer-contact service employees: An empirical investigation', Journal of Marketing, Vol. 60, October, pp. 52-70.

Henneberg, S. C., Gruber, T., Reppel, A., Ashnai, B. and Naudé, P. (2009) 'Complaint management expectations: An online-laddering analysis of small versus large firms', Industrial Marketing Management, Vol. 38, No. 6, pp. 584-598.

Hennig-Thurau, T. (2004) 'Customer orientation of service employees', International Journal of Service Industry Management, Vol. 15, No. 5, pp.460-78.

Heskett, J.J., Jones, T.O., Loveman, G.W. and Schlesinger, L.A. (2008) 'Putting the service-profit chain to work', Harvard Business Review, July-August, pp.118-29.

Hochschild, A.R. (1983) The Managed Heart - Commercialisation of Human Feeling, University of California Press, Berkely, CA.

Holmlund, M. and Kock, S. (1996) 'Relationship marketing: The importance of customer-perceived service quality in retail banking', The Services Industries Journal, Vol. 16, No. 3, pp.287-304.

Jamal, A. and Naser, K. (2002) 'Customer satisfaction and retail banking: An assessment of some key antecedents of customer satisfaction in retail banking', International Journal of Bank Marketing, Vol. 20, No. 4, pp.146-60.

Jaegel, T., Keeling, K., Reppel, A. and Gruber, T. (2012) 'Individual values and motivational complexities in ethical clothing consumption: A means-end approach'. Journal of Marketing Management. Vol. 28, Nos. 3-4, pp. 373-396.

Johnston, R. (1995) 'The determinants of service quality: Satisfiers and dissatisfiers', International Journal of Service Industry Management, Vol. 6, No. 5, pp.53-71.

Johnston, R. (1997) 'Identifying the critical determinants of service quality in retail banking: Importance and effect', International Journal of Bank Marketing, Vol. 15, No. 4, pp.111-16. 
Kelemen, M. and Papasolomou, I. (2007) 'Internal marketing: A qualitative study of culture change in the UK banking sector', Journal of Marketing Management, Vol. 23, No. 7, pp.746-68.

Kelley, S.W. (1992) 'Developing customer orientation among service employees', Journal of the Academy of Marketing Science, Vol. 20, No. 1, pp.27-36.

King, C.A. (1995) 'Viewpoint what is hospitality?', International Journal of Hospitality Management, Vol. 14, No. 3/4, pp.219-34.

Kruml, S. and Geddes, D. (2000) 'Exploring the dimensions of emotional labor: The heart of Hochschild's work', Management Communication Quarterly, Vol. 14, pp.8-49.

Kunz, W. H. and Hogreve, J. (2011) 'Toward a deeper understanding of service marketing: The past, the present, and the future', International Journal of Research in Marketing, Vol. 28, pp. 231-247.

Levesque, T. and McDougall, G.H.G. (1996) 'Determinants of customer satisfaction in retail banking', International Journal of Bank Marketing, Vol. 14, No. 7, pp.12-20.

Lewis, B.R. and Entwistle, T.W. (1990) 'Managing the service encounter: A focus on the employee', International Journal of Service Industry Management, Vol. 1, No. 3, pp.41-52.

Lewis, B.R. and Gabrielson, G.O.S. (1998) 'Intra-organizational aspects of service quality management: The employees perspectives', The Service Industries Journal, Vol. 18, No. 2, pp.64-89.

Lewis, B.R. and Soureli, M. (2006) 'The antecedents of consumer loyalty in retail banking', Journal of Consumer Behaviour, Vol. 5, Februrary, pp.15-31.

Lusch, R.F. and Vargo, S.L. (2006) 'Service-dominant logic: Reactions, reflections and refinements', Marketing Theory, Vol. 6, No. 3, pp.281-88.

Lusch, R.F., Vargo, S.L. and O'Brien, M. (2007) 'Competing through service: Insights from servicedominant logic', Journal of Retailing, Vol. 83, No. 1, pp.5-18.

Malhotra, N.K. and Birks, D.F. (2007) Marketing Research: An Applied Approach, 3rd ed., Prentice Hall, Essex.

Maslow, A.H. (1959) New Knowledge in Human Values, Harper, New York.

Mattila, A.S. and Enz, C.A. (2002) 'The role of emotions in service encounters', Journal of Service Research, Vol. 4, No. 4, pp.268-77.

McCullough, J., Heng, L.S. and Khem, G.S. (1993) 'Measuring the marketing orientation of retail operations of international banks', Journal of Bank Marketing, Vol. 4, No. 3, pp.9-18.

Miles, M.B. and Huberman, A.M. (1994) Qualitative Data Analysis: An Expanded Sourcebook, 2nd ed., Sage, London. 
Mittal, B. and Lassar, W.M. (1996) 'The role of personalisation in service encounters', Journal of Retailing, Vol. 72, No. 1, pp.95-109.

Morgan, R. and Hunt, S. (1994) 'The commitment-trust theory of relationship marketing', Journal of Marketing, Vol. 58, No. 3, pp.20-38.

Nadiri, H., Kandampully, J. and Kashif Hussain, K. (2009) 'Zone of tolerance for banks: A diagnostic model of service quality', The Service Industries Journal, Vol. 29, No. 11, pp.1547-1564.

Olson, J.C. and Reynolds, T.J. (1983) 'Understanding consumers' cognitive structures: implications for marketing strategy', in Percy, L. and Woodside, A.G. (Eds), Advertising and Consumer Psychology, Lexington Books, Lexington, MA, pp. 77-90.

Orsingher, C. and Marzocchi, G.L. (2003) 'Hierarchial representation of satisfactory consumer service experience', International Journal of Service Industry Management, Vol. 14, No. 2, pp.200-16.

Ostrom, A.L., Bitner, M. J., Brown, S. W., Goul, M., Smith-Daniels, V., Demirkan, H., and Rabinovich, E. (2010) 'Moving forward and making a difference: Research priorities for the science of service', Journal of Service Research, Vol. 20, No. 10, pp.1-33.

Papasolomou, I. and Vrontis, D. (2006) 'Building corporate branding through internal marketing: The case of the UK retail banking industry', Journal of Prodcut and Brand Management, Vol. 15, No. 1, pp.37-47.

Parasumaran, A., Berry, L.L. and Zeithaml, V.A. (1991) 'Understanding customer expectations of service', Sloan Management Review, Vol. 32, No. 3, pp.39-48.

Parasuraman, A., Zeithaml, V.A. and Berry, L.L. (1985) 'A conceptual model of service quality and its implications for future research', Journal of Marketing, Vol. 49, Fall, pp.41-50.

Parasuraman, A., Zeithaml, V.A. and Berry, L.L.(1988) 'SERVQUAL: A multiple scale for measuring consumer perceptions of service quality', Journal of Retailing, Vol. 64, No.1, pp.12-39.

Paul, M., Hennig-Thurau, T., Gremler, D. D., Gwinner, K. P. and Wiertz, C. (2009) 'Toward a theory of repeat purchase drivers', Journal of the Academy of Marketing Science, Vol. 37, No. 2, p.215-237.

Payne, A.F., Storbacka, K. and Frow, P. (2008) 'Managing the co-creation of value', Journal of the Academy of Marketing Science, Vol. 36, No. 1, pp.83-96.

Pieters, R., Bottschen, G. and Thelen, E. (1998) 'Customer desire expectations about service employees: An analysis of hierarchical relations', Psychology and Marketing, Vol. 15, No. 8, pp.755-73.

Pine, B.J. and Gilmore, J.H.(1999) The Experience Economy: Work is Theatre and Every Business a Stage, Harvard Business School Press, Boston, MA. 
Prahalad, C.K. and Ramaswamy, V. (2004) 'Co-creation experiences: The next practice in value creation', Journal of Interactive Marketing, Vol. 18, No. 3, pp.5-14.

Price, L.L. and Arnould, E.T. (1999) 'Commercial friendships: Service provider-client relationships in context', Journal of Marketing, Vol. 36, No. 4, pp.38-56.

Pullman, M.E. and Gross, M.A. (2004) 'Ability of experience design elements to elicit emotions and loyalty behaviours', Decison Sciences, Vol. 35, No. 3, pp.551-78.

Rafiq, M. and Ahmed, P.K. (1998) 'A customer-oriented framework for empowering service employees', The Journal of Services Marketing, Vol. 12, No. 5, pp.379-96.

Ramsey, R.P. and Sohi, R.S. (1997) 'Listening to your customers: The impact of perceived salesperson listening behaviour on relationship outcomes', Journal of the Academy of Marketing Science, Vol. 25, No. 2, pp.127-37.

Reichheld, F.F. and Sasser, W.E. (1990) 'Zero defections: Quality comes to services', Harvard Business Review, September-October, pp.105-11.

Reinartz, W.J. and Kumar, V. (2003) 'The impact of relatonship characteristics on profitable lifetime duration', Journal of Marketing, Vol. 67, January, pp.77-99.

Reynolds, T. and Gutman, J. (1988) 'Laddering theory, method, analysis, and interpretation', Journal of Advertising Research, Vol. 28, No. 1, pp. 11 - 31.

Reynolds, T.J. and Gutman, J. (2001) 'Laddering theory, method, analysis and interpretation', in Reynolds, T. J. and Olson, J. C. (Eds.), Understanding Consumer Decision Making-The Means-End Approach to Marketing and Advertising Strategy, Lawrence Erlbaum Associates, Mahwah, NJ, pp.25-63.

Reynolds, T. J, Dethloff, C. and Westberg, S. J. (2001) ‘Advances in laddering', in Reynolds, T. J. and Olson, J. C. (Eds.), Understanding Consumer Decision Making-The Means-End Approach to Marketing and Advertising Strategy, Lawrence Erlbaum Associates, Mahwah, NJ, pp. 91-11.

Richardson, B.A. and Robinson, C.G. (1993) 'The impact of internal marketing on customer service in a retail bank', International Journal of Bank Marketing, Vol. 4, No. 5, pp.3-30.

Rokeach, M. (1973), The Nature of Human Values, Free Press, New York, NY.

Schmitt, B.H. (1999) Experiental Marketing: How to Get Customers to Sense, Feel, Think, Act, Relate, Simon and Schuster, New York, NY.

Schneider, B. (1980) 'The service organisation: Climate is crucial', Organizational Dynamics, Vol. 9, No. 3, pp.52-65. 
Schneider, B. and Bowen, D.E. (1985) 'Employee and customer perceptions of service in banks: Replication and extension', Journal of Applied Psychology, Vol. 70, No. 3, pp.423-33.

Shemwell, D.J., Cronin, J.J. and Bullard, W.R. (1994) 'Relational exchange in services: An empirical investigation of ongoing customer-service provider relationships', International Journal of Service Industry Management, Vol. 5, No. 3, pp.57-68.

Singh, J. (1993) 'Boundary role ambiguity: Facets, determinants and impacts', Journal of Marketing, Vol. 57, April, pp.11-31.

Solomon, M.R., Surprenant, C., Czepiel, J.A. and Gutman, E.G. (1985) 'A role theory perspective: On dyadic interactions: the service encounter', Journal of Marketing, Vol. 49, No. 1, pp.99-111.

Surprenant, C. and Solomon, M. (1987) 'Predictability and personalisation in the service encounter', Journal of Marketing, Vol. 51, No. 3, pp.34-43.

Svensson, G. (2001) 'The quality of bi-directional service quality in dyadic service encounters', Journal of Services Marketing, Vol. 15, No. 5, pp.357-78.

Svensson, G. (2006), 'New aspects of research into service encounters and service quality', International Journal of Service Industry Management, Vol. 17 No. 3, pp.245-57.

Swan, J.E., Bowers, M.R. and Richardson, L.D. (1999) 'Customer trust in the salesperson: An integrative review and meta-analysis of the empirical literature', Journal of Business Research, Vol. 44, pp.93-107.

Swartz, T.A. and Brown, S.W. (1989) 'Consumer and provider expectations and experiences in evaluating professional service quality', Journal of the Academy of Marketing Science, Vol. 17, No. 2, pp.189-95.

Tam, J.L.M. and Wong, Y.H. (2001) 'Interactive selling: A dynamic framework for services', Journal of Services Marketing, Vol. 15, No. 5, pp.379-96.

Tansuhaj, P., Wong, J. and McCullough, J. (1987) 'Internal and external marketing: Effects on consumer satisfaction in banks in Thainland', International Journal of Bank Marketing, Vol. 5, No. 3, pp.73-83.

Tortosa, V., Moline, M.A. and Sanchez, J. (2009) 'Internal market orientation and its influence on organisational performance', European Journal of Marketing, Vol. 43, No. 11/12, pp.1435-56.

Van Rekom, J. and Wierenga, B. (2007) 'On the hierarchical nature of means-end relationships in laddering data', Journal of Business Research, Vol. 60, No. 4, pp. 401-10. 
Vargo, S. L. (2008) 'Customer integration and value creation: paradigmatic traps and perspectives', Journal of Service Research, Vol. 11, No. 2, pp. 211-215.

Vargo, S. L. (2009) 'Toward a transcending conceptualisation of relationship: A service-dominant logic perspective', Journal of Business and Industrial Marketing, Vol. 11, No. 2, pp.373-79.

Vargo, S. L., and Lusch, R. F. (2004) 'Evolving to a new dominant logic for marketing', Journal of Marketing, Vol. 68, No. 1, pp. 1-17.

Vargo, S.L. and Lusch, R. F. (2006) 'Service-dominant logic: What it is, what it is not, what it might be', in Lusch, R. F. and Vargo, S. F. (Eds.), The Service-Dominant Logic of Marketing: Dialog, Debate, and Directions, M. E. Shape, New York, NY, pp. 43-56.

Vargo, S.L., and Lusch, R.F. (2008a) 'Why 'service'?', Journal of the Academy of Marketing Science, Vol. 36, No. 1, pp. 25-38.

Vargo, S.L., and Lusch, R.F. (2008b) 'From goods to service(s): divergences and convergences of logics', Industrial Marketing Management, Vol. 37, No. 3, pp. 254-259.

Vargo, S.L., and Lusch, R.F. (2008c) 'Service-dominant logic: continuing the evolution', Journal of the Academy of Marketing Science, Vol. 36, No. 1, pp. 1-10.

Vargo, S.L. and Lusch, R.F. (2011) 'It's all B2B...and beyond: Toward a systems perspective of the market', Industrial Marketing Management, 40, pp. 181-187.

Vargo, S. L., Maglio, P. P. and Akaka, M.A. (2008) 'On value and value co-creation: A service systems and service logic perspective', European Management Journal, Vol. 26, pp.145-52.

Voss, R. and Gruber, T. (2006) 'The desired teaching qualities of lecturers in higher education: A means-end analysis', Quality Assurance in Education, Vol. 14, No. 3, pp.217-42.

Wagner, T. (2007) 'Shopping motivation revised: A means-end chain analytical perspective', International Journal of Retail and Distribution Management, Vol. 35, No. 7, pp.569-82.

Warhurst, C., Nickson, D., Wirtz, A. and Cullen, M. (2000) 'Aesthic labour in interactive service work: Some case study evidence from the 'new Glasgow', The Service Industries Journal, Vol. 20, No. 3, pp.1-18.

Winsted, K.F. (2000) 'Service behaviors that lead to satisfied customers', European Journal of Marketing, Vol. 34, Nos. 3/4, pp.399-417.

Zeithaml, V.A., Berry, L.L. and Parasuraman, A. (1993) 'The nature and determinants of customer expectations of service', Journal of the Academy of Marketing Science, Vol. 21, No. 1, pp.1-12. 
Zeithaml, V.A., Berry, L.L. and Parasuraman, A. (1996) 'The behavioral consequences of service quality', Journal of Marketing, Vol. 60, April, pp.31-46.

Zeithaml, V.A., Parasuraman, A. and Berry, L.L. (1988) 'Communications and control process in the delivery of service quality', Journal of Marketing, Vol. 52, April, pp.35-48.

Zomerdijk, L.G. and Voss, C.A. (2010) 'Service design for experience-centric services', Journal of Service Research, Vol. 13, No. 1, pp.67-82. 
Figure 1 Hierarchical value map (HVM) for customers

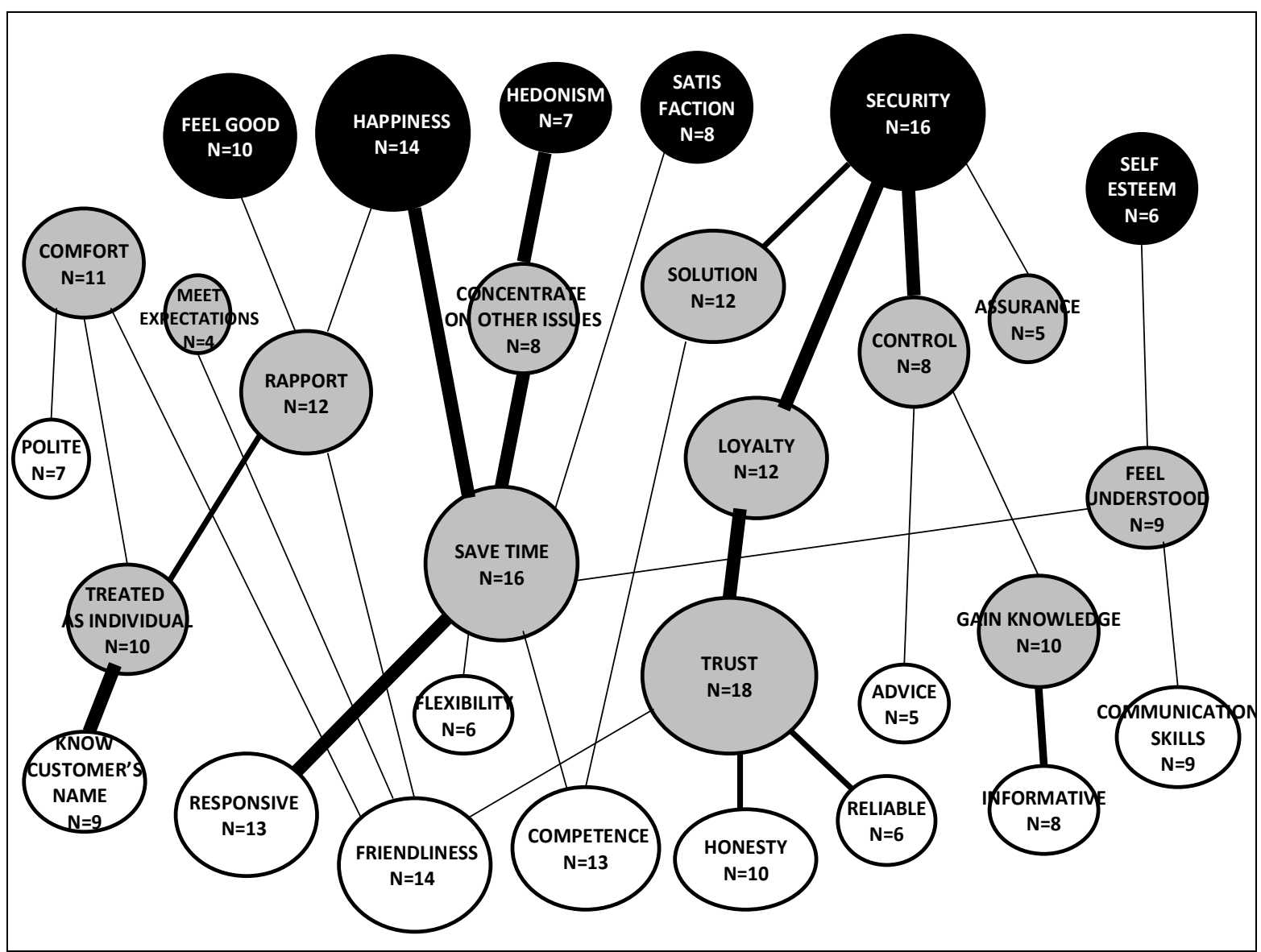

Note: Attributes=white, consequences=grey and values=black; numbers $(N)$ refer to the frequency with which concept was mentioned 
Figure 2 Hierarchical value map (HVM) for employees

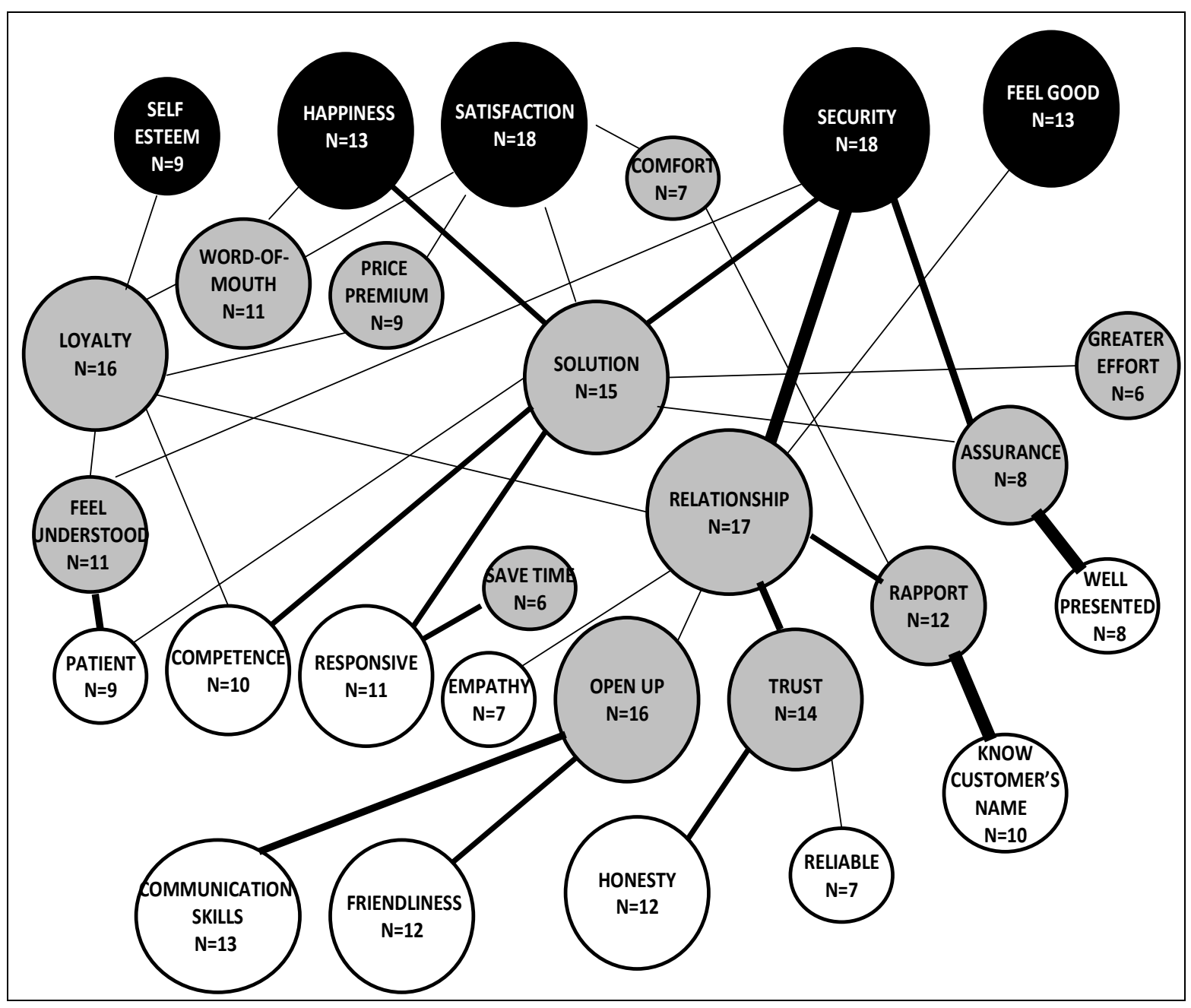


Table 1 Characteristics of customer and frontline employee sample

\begin{tabular}{|c|c|c|}
\hline & Customers & Employees \\
\hline $\begin{array}{c}\text { Number of } \\
\text { participants }\end{array}$ & 20 & 20 \\
\hline \multicolumn{3}{|l|}{ Grender } \\
\hline Female & 550 & $100 \%$ \\
\hline Male & $45 \%$ & $60 \%$ \\
\hline \multicolumn{3}{|l|}{ Age (in years) } \\
\hline Average & 24.5 & 39.5 \\
\hline Minimum & 21 & 26 \\
\hline Maximum & 65 & 55 \\
\hline \multicolumn{3}{|c|}{$\begin{array}{c}\text { Tears of } \\
\text { patronage enployment }\end{array}$} \\
\hline Average & 12.75 & 14.1 \\
\hline Minimmim & 1 & 2 \\
\hline Maximmm & 35 & 30 \\
\hline
\end{tabular}


Table 2 Overview of attributes

\begin{tabular}{|c|c|c|c|c|}
\hline $\begin{array}{l}\text { Name of } \\
\text { Attribute }\end{array}$ & $\begin{array}{c}\text { Number of } \\
\text { times } \\
\text { mentioned } \\
\text { by } \\
\text { customers } \\
\text { (in } \\
\text { ladders) }\end{array}$ & $\begin{array}{c}\text { Number of } \\
\text { times } \\
\text { mentioned } \\
\text { by } \\
\text { employees } \\
\text { (in } \\
\text { ladders) }\end{array}$ & Description & $\begin{array}{l}\text { Similar concepts in } \\
\text { literature }\end{array}$ \\
\hline Accurateness & 1 & 0 & $\begin{array}{l}\text { Employees should provide the } \\
\text { service without making any error } \\
\text { and be accurate with numbers. }\end{array}$ & $\begin{array}{l}\text { Accurateness (Gruber et } \\
\text { al., 2006) }\end{array}$ \\
\hline Advice & 5 & 2 & $\begin{array}{l}\text { Employee should advise } \\
\text { customers in order to help } \\
\text { customers to make the right } \\
\text { decision. }\end{array}$ & $\begin{array}{l}\text { Advice (Pieters et al., } \\
\text { 1998) }\end{array}$ \\
\hline Approachable & 6 & 1 & $\begin{array}{l}\text { Employees should be helpful } \\
\text { when dealing with customer } \\
\text { requests. }\end{array}$ & $\begin{array}{l}\text { Approachable } \\
\text { (Voss and Gruber, 2006) }\end{array}$ \\
\hline $\begin{array}{l}\text { Communication } \\
\text { skills }\end{array}$ & 10 & 13 & $\begin{array}{l}\text { Employees should have good } \\
\text { communication skills, be able to } \\
\text { interact and be a good listener. }\end{array}$ & $\begin{array}{l}\text { Communication skills } \\
\text { (Voss and Gruber, 2006); } \\
\text { Listening skills (Deeter- } \\
\text { Schmelz et al.2002) }\end{array}$ \\
\hline Competence & 13 & 10 & $\begin{array}{l}\text { Employees should have } \\
\text { knowledge about the } \\
\text { product/service and prove to be } \\
\text { experts in their fields. }\end{array}$ & $\begin{array}{l}\text { Competence (Gruber et } \\
\text { al., 2006; Pieters et al., } \\
\text { 1998); Expertise (Voss } \\
\text { and Gruber, 2006; Brady } \\
\text { and Cronin, 2010) }\end{array}$ \\
\hline Empathy & 7 & 7 & $\begin{array}{l}\text { Employees should take care of } \\
\text { and show interest in all } \\
\text { customers. }\end{array}$ & $\begin{array}{l}\text { Empathy (Gruber et al., } \\
\text { 2006; Parasumaran et al., } \\
\text { 1985,1988; Cronin and } \\
\text { Taylor, 1992; Hennig- } \\
\text { Thurgau, 2004; Zeithaml } \\
\text { et al. 1996) }\end{array}$ \\
\hline Enthusiasm & 2 & 0 & $\begin{array}{l}\text { Employees should be enthusiastic } \\
\text { when dealing with customers and } \\
\text { create the impression that they } \\
\text { enjoy their work. }\end{array}$ & $\begin{array}{l}\text { Enthusiasm (Voss and } \\
\text { Gruber, 2006) }\end{array}$ \\
\hline Flexibility & 9 & 0 & $\begin{array}{l}\text { Employees should be flexible and } \\
\text { less strict with regulations; they } \\
\text { should not strictly follow the } \\
\text { code of conduct of the bank. }\end{array}$ & N/A \\
\hline Friendliness & 14 & 12 & $\begin{array}{l}\text { Employees should be friendly, } \\
\text { smiling, courteous and } \\
\text { welcoming. }\end{array}$ & $\begin{array}{l}\text { Friendliness (Gruber et } \\
\text { al., 2006; Courtesy } \\
\text { (Winsted, 2000) }\end{array}$ \\
\hline Honesty & 11 & 12 & $\begin{array}{l}\text { Employees should tell customers } \\
\text { the truth and not hide details } \\
\text { about charges or interest rates. }\end{array}$ & $\begin{array}{l}\text { Honesty (Gruber et al, } \\
2006,2008 \text { ) }\end{array}$ \\
\hline Informative & 8 & 2 & $\begin{array}{l}\text { Employees should be willing to } \\
\text { answer questions, explain } \\
\text { procedures and inform customers } \\
\text { about changes in their accounts; } \\
\text { be willing to share information. }\end{array}$ & $\begin{array}{l}\text { Co-create conversation } \\
\text { and dialogue (Lusch et } \\
\text { al., 2007) }\end{array}$ \\
\hline $\begin{array}{l}\text { Know } \\
\text { customer's } \\
\text { name }\end{array}$ & 9 & 10 & $\begin{array}{l}\text { Employees should know and use } \\
\text { a customer's name. }\end{array}$ & $\begin{array}{l}\text { Use of customer's name } \\
\text { (Goodwin and Smith, } \\
\text { 1990; Schneider, 1980) }\end{array}$ \\
\hline
\end{tabular}




\begin{tabular}{|c|c|c|c|c|}
\hline Motivation & 0 & 1 & $\begin{array}{l}\text { Employees should demonstrate } \\
\text { effort in service provision and } \\
\text { have a good job attitude. }\end{array}$ & $\begin{array}{l}\text { Motivation (Gruber et } \\
\text { al., 2006) }\end{array}$ \\
\hline Objectivity & 6 & 5 & $\begin{array}{l}\text { Employees should be fair and } \\
\text { provide the same service to every } \\
\text { customer. }\end{array}$ & $\begin{array}{l}\text { Objectivity (Gruber et } \\
\text { al., 2006) }\end{array}$ \\
\hline Patient & 7 & 9 & $\begin{array}{l}\text { Employees should give } \\
\text { customers the time to understand } \\
\text { the service and they should take } \\
\text { the time to explain it in detail. }\end{array}$ & $\begin{array}{l}\text { Take time (Gruber et al., } \\
2006 \text { ) }\end{array}$ \\
\hline Polite & 7 & 4 & Employees should be polite. & $\begin{array}{l}\text { Polite (Cronin and } \\
\text { Taylor, 1992; Pieters et } \\
\text { al., 1998) }\end{array}$ \\
\hline Proactive & 2 & 2 & $\begin{array}{l}\text { Employees should take care of } \\
\text { customer accounts and inform } \\
\text { them about changes or any } \\
\text { problems with the account prior } \\
\text { to customer noticing it; give } \\
\text { information before customers ask } \\
\text { for it. }\end{array}$ & $\begin{array}{l}\text { Motivation (Paul et al., } \\
\text { 2009); } \\
\text { Proactiveness } \\
\text { (Henneberg et al., 2009) }\end{array}$ \\
\hline Reliable & 7 & 7 & $\begin{array}{l}\text { Employees should perform the } \\
\text { service as promised in order to } \\
\text { give customers security and the } \\
\text { feeling that they can rely on them } \\
\text { in the future. }\end{array}$ & $\begin{array}{l}\text { Reliability (Parasumaran } \\
\text { et al., 1985,1988; Cronin } \\
\text { and Taylor, 1992; } \\
\text { Zeithaml et al. 1996) }\end{array}$ \\
\hline Respectful & 4 & 2 & $\begin{array}{l}\text { Employees should treat } \\
\text { customers with respect. }\end{array}$ & Respectful (King, 1995) \\
\hline Responsibility & 1 & 0 & $\begin{array}{l}\text { Employees should take } \\
\text { responsibility for their actions. }\end{array}$ & $\begin{array}{l}\text { Responsibility (Gruber et } \\
\text { al., 2006) }\end{array}$ \\
\hline Responsive & 14 & 12 & $\begin{array}{l}\text { Employees should be efficient } \\
\text { and give a prompt service; there } \\
\text { should be a short waiting time in } \\
\text { the bank. }\end{array}$ & $\begin{array}{l}\text { Responsiveness } \\
\text { (Parasumaran et al., } \\
\text { 1985,1988; Cronin and } \\
\text { Taylor 1992; Barger and } \\
\text { Grandey, 2006) }\end{array}$ \\
\hline Well presented & 1 & 8 & $\begin{array}{l}\text { Employees should be dressed } \\
\text { well and look professional. }\end{array}$ & $\begin{array}{l}\text { Presentable (Warhurst et } \\
\text { al., 2000) }\end{array}$ \\
\hline
\end{tabular}


Table 3 Overview of consequences

\begin{tabular}{|c|c|c|c|c|}
\hline $\begin{array}{c}\text { Name of } \\
\text { Consequence }\end{array}$ & $\begin{array}{c}\text { Number of } \\
\text { times } \\
\text { mentioned } \\
\text { by } \\
\text { customers } \\
\text { (in } \\
\text { ladders) }\end{array}$ & $\begin{array}{c}\text { Number of } \\
\text { time } \\
\text { mentioned } \\
\text { by } \\
\text { employees } \\
\text { (in } \\
\text { ladders) }\end{array}$ & Description & $\begin{array}{l}\text { Similar concepts in } \\
\text { literature }\end{array}$ \\
\hline Assurance & 4 & 10 & $\begin{array}{l}\text { Customers want to be sure that } \\
\text { their request will be handled } \\
\text { professionally. }\end{array}$ & $\begin{array}{l}\text { Assurance (Parasumaran } \\
\text { et al., 1985, 1988) }\end{array}$ \\
\hline Calm down & 1 & 0 & $\begin{array}{l}\text { Customers feel at ease if } \\
\text { employees stay calm and relaxed. }\end{array}$ & $\begin{array}{l}\text { Calm down (Gruber et al., } \\
2006)\end{array}$ \\
\hline Comfort & 14 & 7 & $\begin{array}{l}\text { Customers want to feel } \\
\text { comfortable during their stay in } \\
\text { the bank. }\end{array}$ & $\begin{array}{l}\text { Comfort (Gruber et al., } \\
\text { 2006) }\end{array}$ \\
\hline $\begin{array}{l}\text { Concentrate on } \\
\text { other issues }\end{array}$ & 9 & 0 & $\begin{array}{l}\text { Customers want to use their time } \\
\text { to devote attention to other issues. }\end{array}$ & $\begin{array}{l}\text { Concentrate on other } \\
\text { issues (Gruber et al., } \\
2006)\end{array}$ \\
\hline Control & 10 & 2 & $\begin{array}{l}\text { Customers want to have control } \\
\text { over their money and know the } \\
\text { next step in the process in order to } \\
\text { make their own and the right } \\
\text { decision. }\end{array}$ & $\begin{array}{l}\text { Decisional control } \\
\text { (Solomon et al., 1985) }\end{array}$ \\
\hline Feel cared for & 4 & 1 & $\begin{array}{l}\text { Customers want to feel that they } \\
\text { are taken care of and welcome in } \\
\text { the bank. }\end{array}$ & $\begin{array}{l}\text { Good treatment (Gruber } \\
\text { et al., 2006); Feeling } \\
\text { looked after (Orsingher } \\
\text { and Marzocchi, 2003); } \\
\text { Welcomeness (Paul et al., } \\
\text { 2009) } \\
\end{array}$ \\
\hline Feel respected & 1 & 0 & $\begin{array}{l}\text { Customers want to feel respected } \\
\text { by employees. }\end{array}$ & $\begin{array}{l}\text { Respect (Botschen et al., } \\
\text { 1999) }\end{array}$ \\
\hline Feel understood & 12 & 16 & $\begin{array}{l}\text { Customers want to feel that } \\
\text { employees understand them and } \\
\text { their needs; and feel accepted. }\end{array}$ & $\begin{array}{l}\text { Affiliation (Paul et al., } \\
\text { 2009) }\end{array}$ \\
\hline Gain knowledge & 13 & 4 & $\begin{array}{l}\text { Customers want to understand the } \\
\text { service provided and learn more } \\
\text { about the product/service. }\end{array}$ & $\begin{array}{l}\text { Learning (Gruber et al., } \\
\text { 2009a) }\end{array}$ \\
\hline Greater effort & 3 & 6 & $\begin{array}{l}\text { Customers want to see that } \\
\text { employees do their best to satisfy } \\
\text { their request. }\end{array}$ & $\begin{array}{l}\text { Greater effort (Deeter- } \\
\text { Schmelz et al., 2002) }\end{array}$ \\
\hline Loyalty & 16 & 24 & $\begin{array}{l}\text { Customers will stay with the } \\
\text { bank. }\end{array}$ & $\begin{array}{l}\text { Loyalty (Reichheld and } \\
\text { Sasser, 1990; Gremler and } \\
\text { Gwinner, 2000) }\end{array}$ \\
\hline $\begin{array}{l}\text { Meet } \\
\text { expectations }\end{array}$ & 4 & 3 & $\begin{array}{l}\text { Customers want employees to } \\
\text { meet their expectations as; certain } \\
\text { employee characteristics are taken } \\
\text { for granted by customers. }\end{array}$ & $\begin{array}{l}\text { Expectation } \\
\text { (Deeter-Schmelz et al., } \\
2008 \text { ) }\end{array}$ \\
\hline Open up & 4 & 22 & $\begin{array}{l}\text { Customers want to feel that they } \\
\text { can speak freely to the employees } \\
\text { about their needs. }\end{array}$ & $\begin{array}{l}\text { Openness (Gruber et al.,, } \\
\text { 2006) }\end{array}$ \\
\hline Price premium & 0 & 10 & $\begin{array}{l}\text { Customers are willing to pay } \\
\text { more or higher interest rates if } \\
\text { they are satisfied with the service } \\
\text { provided. }\end{array}$ & $\begin{array}{l}\text { Price premium } \\
\text { (Reichheld and Sasser, } \\
\text { 1990) }\end{array}$ \\
\hline
\end{tabular}




\begin{tabular}{|c|c|c|c|c|}
\hline Rapport & 15 & 15 & $\begin{array}{l}\text { Customers want to have a } \\
\text { personal connection with the } \\
\text { employees. }\end{array}$ & $\begin{array}{l}\text { Rapport (Gremler and } \\
\text { Gwinner, 2000) }\end{array}$ \\
\hline Relationship & 7 & 26 & $\begin{array}{l}\text { Customers want to have a } \\
\text { personal bond with employees; an } \\
\text { ongoing relationship with the } \\
\text { employee. }\end{array}$ & $\begin{array}{l}\text { Relationship (Pullman } \\
\text { and Gross, 2004; Reinartz } \\
\text { and Kumar, 2003) }\end{array}$ \\
\hline Reputation & 0 & 4 & $\begin{array}{l}\text { Customers will have a good } \\
\text { impression about the bank. }\end{array}$ & $\begin{array}{l}\text { Company image (Tam } \\
\text { and Wong, 2001) }\end{array}$ \\
\hline Respect others & 5 & 2 & $\begin{array}{l}\text { Customers respect other } \\
\text { customers and their needs. }\end{array}$ & $\begin{array}{l}\text { Community (Paul et al., } \\
\text { 2009) }\end{array}$ \\
\hline Save time & 27 & 6 & $\begin{array}{l}\text { Customers want the request to be } \\
\text { dealt with quickly so they can } \\
\text { save time. }\end{array}$ & $\begin{array}{l}\text { Save time (Gruber et al., } \\
\text { 2006) }\end{array}$ \\
\hline Solution & 17 & 25 & $\begin{array}{l}\text { Customers want the employees to } \\
\text { fulfil their request. }\end{array}$ & $\begin{array}{l}\text { Solution (Gruber et al., } \\
2006 \text { ) }\end{array}$ \\
\hline $\begin{array}{l}\text { Take someone } \\
\text { seriously }\end{array}$ & 2 & 3 & $\begin{array}{l}\text { Customers want to have the } \\
\text { feeling to be taking seriously. }\end{array}$ & $\begin{array}{l}\text { Take someone seriously } \\
\text { (Gruber et al., 2006) }\end{array}$ \\
\hline $\begin{array}{l}\text { Treated as } \\
\text { individual }\end{array}$ & 11 & 2 & $\begin{array}{l}\text { Customers want to be treated like } \\
\text { individuals, not like numbers. }\end{array}$ & $\begin{array}{l}\text { Show concern for } \\
\text { customer (Bitran and } \\
\text { Hoech, 1990); Good } \\
\text { treatment (Gruber et al., } \\
2006)\end{array}$ \\
\hline Trust & 27 & 20 & $\begin{array}{l}\text { Customers want to feel that they } \\
\text { can trust and have confidence in } \\
\text { employees' abilities. }\end{array}$ & $\begin{array}{l}\text { Trust (Gruber et al., } \\
2006,2008)\end{array}$ \\
\hline Word-of-mouth & 1 & 14 & $\begin{array}{l}\text { Customers will recommend the } \\
\text { bank to their friends/family. }\end{array}$ & $\begin{array}{l}\text { Word-of-mouth (Gremler } \\
\text { and Gwinner, 2000; } \\
\text { Zeithaml et al., 1993) }\end{array}$ \\
\hline
\end{tabular}


Table 4 Overview of values

\begin{tabular}{|c|c|c|c|c|}
\hline Name of value & $\begin{array}{c}\text { Number } \\
\text { of times } \\
\text { mentioned } \\
\text { by } \\
\text { customers } \\
\text { (in } \\
\text { ladders) }\end{array}$ & $\begin{array}{c}\begin{array}{c}\text { Numbers } \\
\text { of time }\end{array} \\
\text { mentioned } \\
\text { by } \\
\text { employees } \\
\text { (in } \\
\text { ladders) }\end{array}$ & Description & $\begin{array}{l}\text { Similar concepts in } \\
\text { literature }\end{array}$ \\
\hline Accomplishment & 3 & 0 & $\begin{array}{l}\text { Customers want to carry on and } \\
\text { achieve their goals (work etc). }\end{array}$ & $\begin{array}{l}\text { Sense of } \\
\text { accomplishment } \\
\text { (Rokeach, 1973) }\end{array}$ \\
\hline Equality & 6 & 2 & $\begin{array}{l}\text { Customers want the same service } \\
\text { provided to every customer. }\end{array}$ & $\begin{array}{l}\text { Equality (Rokeach, } \\
\text { 1973) }\end{array}$ \\
\hline Feel good & 13 & 15 & $\begin{array}{l}\text { Customers want to feel good } \\
\text { during their visit. }\end{array}$ & $\begin{array}{l}\text { Feeling good (Botschen } \\
\text { et al., 1999) }\end{array}$ \\
\hline Happiness & 19 & 19 & Customers want to be happy. & $\begin{array}{l}\text { Happiness (Wagner, } \\
\text { 2007; Rokeach, 1973) }\end{array}$ \\
\hline Hedonism & 7 & 0 & Customers want to enjoy life. & $\begin{array}{l}\text { Hedonism (Burgess and } \\
\text { Steenkamp, 1999); } \\
\text { Pleasure (Rokeach, } \\
1973 \text { ) }\end{array}$ \\
\hline Satisfaction & 12 & 30 & Customers want to be satisfied. & $\begin{array}{l}\text { Satisfaction (Gruber et } \\
\text { al., 2006) }\end{array}$ \\
\hline Security & 55 & 29 & $\begin{array}{l}\text { Customers want to have certainty } \\
\text { and feel safe and secure. }\end{array}$ & $\begin{array}{l}\text { Safety (Maslow, 1959); } \\
\text { Security (Gruber et al., } \\
\text { 2006; Voss and Gruber, } \\
2006 \text { ) }\end{array}$ \\
\hline Self-esteem & 11 & 12 & $\begin{array}{l}\text { Customers want to feel special } \\
\text { and important. }\end{array}$ & $\begin{array}{l}\text { Self-esteem (Maslow, } \\
\text { 1959); Self-worth } \\
\text { (Reynolds and Gutman, } \\
\text { 1988) }\end{array}$ \\
\hline Well-being & 13 & 9 & $\begin{array}{l}\text { Customers want employees to be } \\
\text { concerned about their well-being. }\end{array}$ & $\begin{array}{l}\text { Well-being (Gruber et } \\
\text { al., 2006) }\end{array}$ \\
\hline
\end{tabular}


Table 5 Extract from implication matrix (customer subgroup)

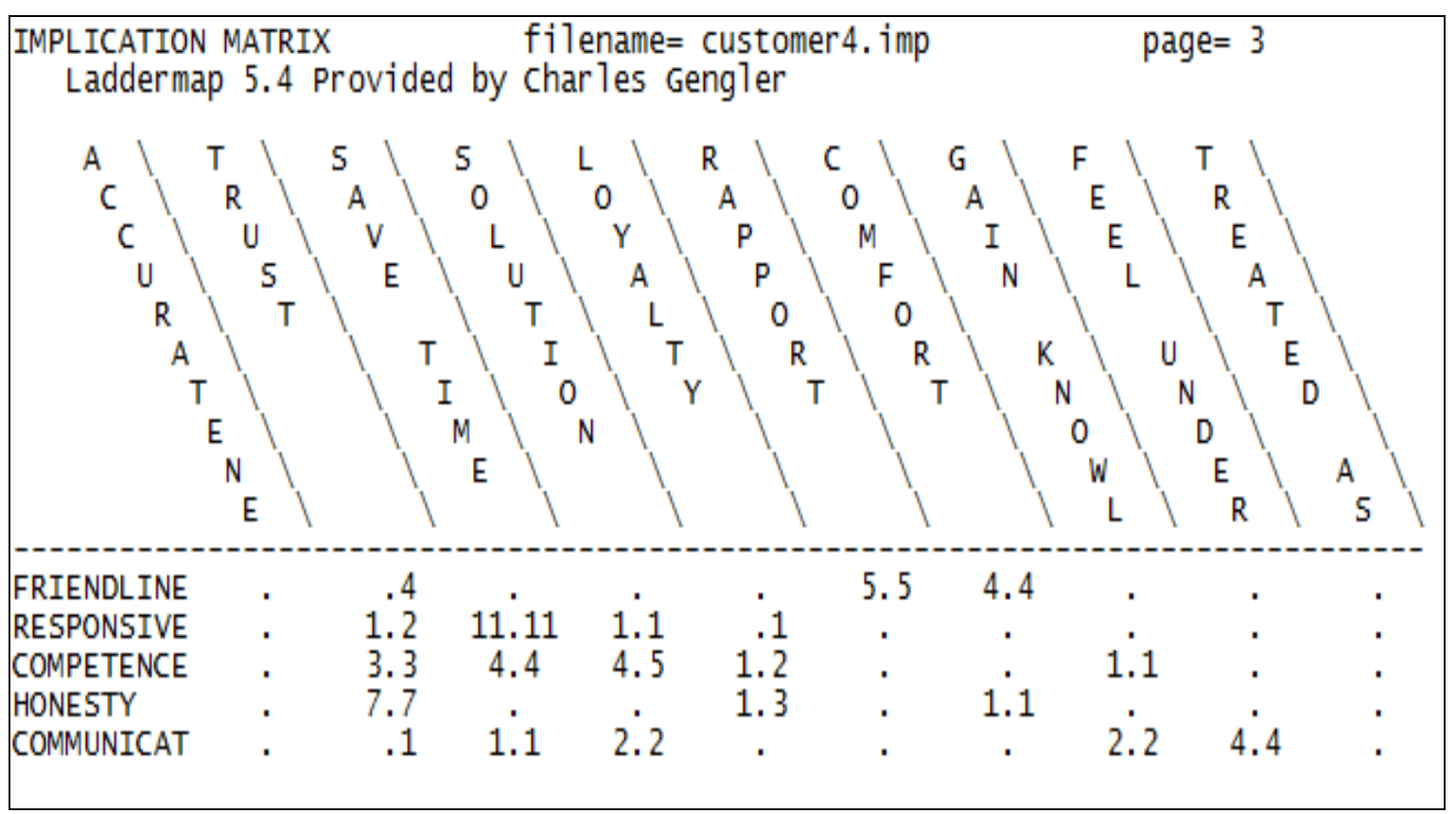

